
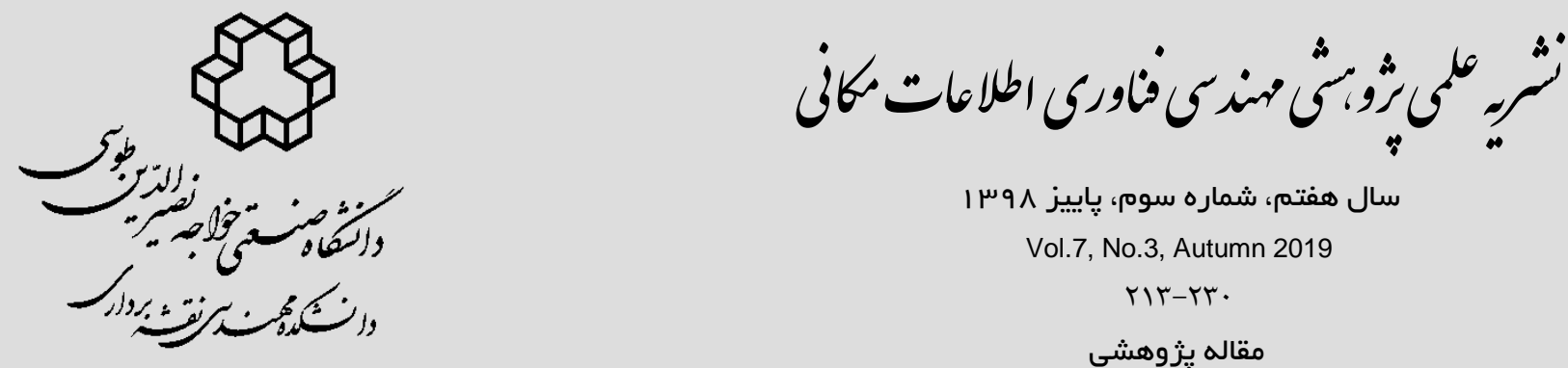

سال هفتمم، شماره سوم، ياييز ^وسر

Vol.7, No.3, Autumn 2019

rIT-rr.

مقاله يُزوهشى

بر آورد زيست توده درختان با استفاده از ابر نقاط متراكم استخراج شده از تصاوير يهیياد در سطح تكىرخت، قطعه نمونه و تركيبى

\author{
محمدرضا كاركر ' ،حمزه سهرابى 'م"

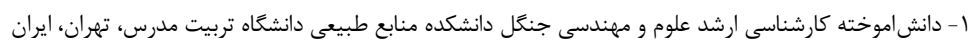

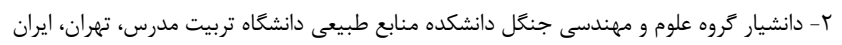

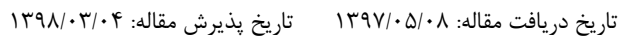

جكيده

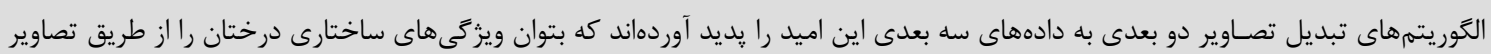

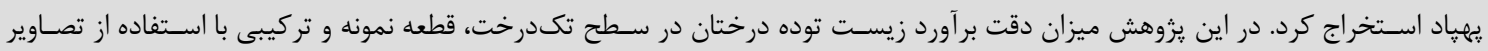

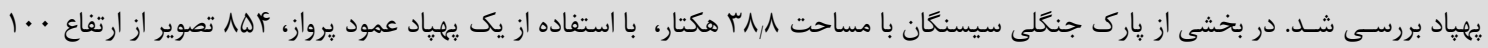

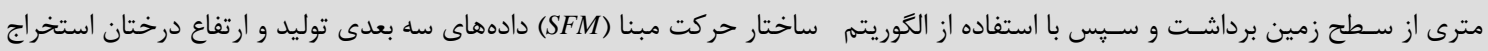

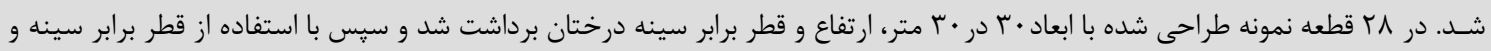

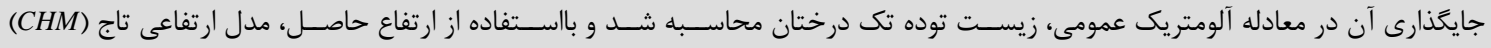

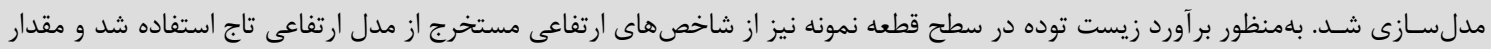

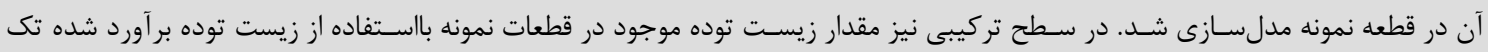

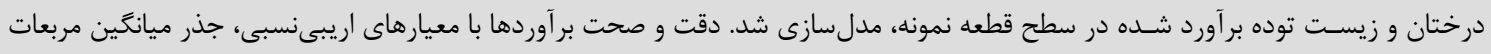

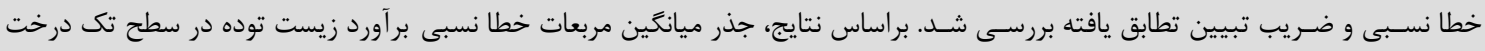

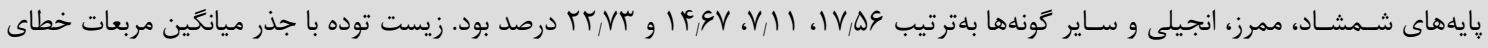

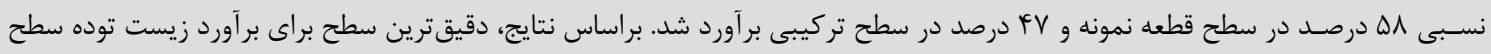

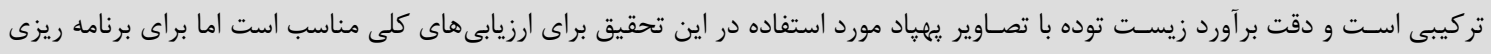
مديريتى دقت لازم راندارد.

كليدوازهها: يِهياد، سيسنگًان، مدل ارتفاعى تاج، زيست توده روى زمين، مدل رقومى زمين.

قُنويسنده مكاتبه كننده: مازندران، شهرستان نور، خيابان امام خمينى، بلوار امام رضا، دانشكده منابع طبيعى و علوم دريايى دانشًاه تربيت مدرس.

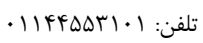

Email:hsohrabi@modares.ac.ir 
است كه تبديل به بافت كياهى شـده اسـت. بــه منظـور

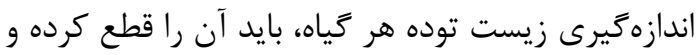
وزن خشك آن را محاسبه شود؛ امـا ايـن روش مخــرب است و موجب از بين رفتن درخت، بنابراين براى برآورد

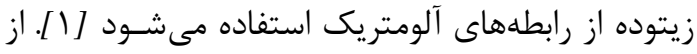

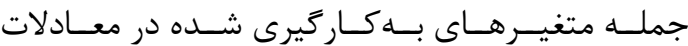
آلومتريك، مشخصههاى بيـوفيزيكى درختــان هسـتـند. قطر تاج، ارتفاع درختـان، قطـر برابـر سـينه و غيـره، از

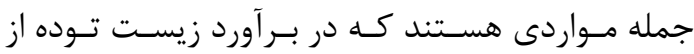

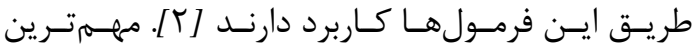
روشهاى برداشت يارامترها به منظــور محاسـبه ميـزان زيست توده روى زمين در جدول (1) ذكر شـده اسـت.

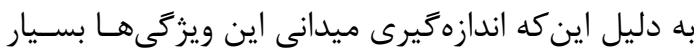
طاقتفرساست و گاها همراه با خسارات جبــران نايـذير

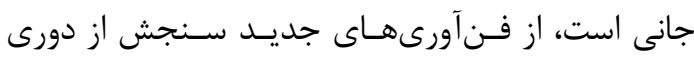

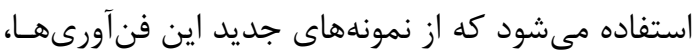

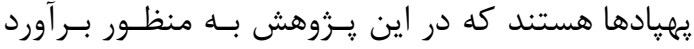

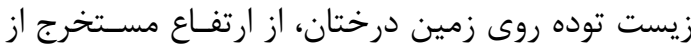

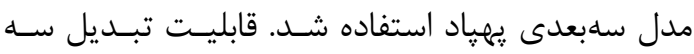
بعدى در تصاوير يهيادها و تفكيكهاى مختلف مكانى و زمانى قابل برنامهريزى آنها، خدمات بسـيار ويـزماى را در زمينه علوم جنگل ارائه كرده است.

I-Y- سه بعدى سازى تصاوير يهياد استخراج ابـر تقـاط متـراكم توسـط الخــوريتم سـاختار حر كت مبنا (SFM) صـورت مسى

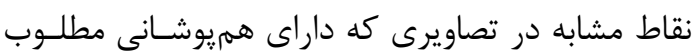
هستند را به عنوان نقاط كليدى انتخاب كرده و تصـاوير

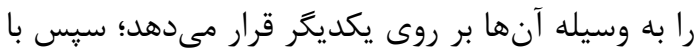

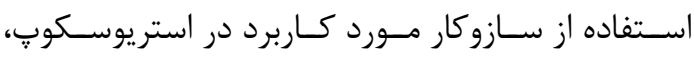

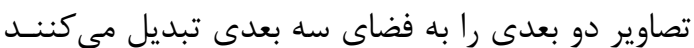
[9]. ميزان همريوشانى در تصاوير اخــذ شـده بـهـوسـيله

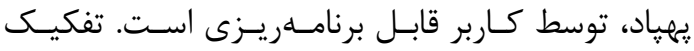

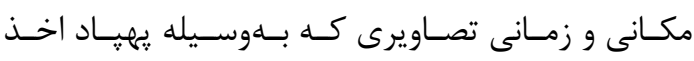

${ }^{2}$ Structure from Motion

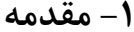

محصولات سنجشازدورى از مهممترين دادههايى هستند كه امروزه در تـامين منــابع مــورد نيـاز بـراى مـديريت

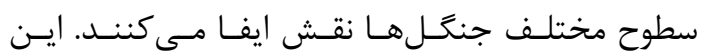

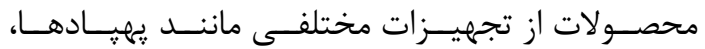
ماهوارههـا، هواييمـاهــاى سرنشـيندار و غيـره حاصـل مىشوند. يهيادها تجهيزات نوظهورى هستند كه ارتفـاع فعاليت آنها كمتر از تجهيزات هوابرد بـوده و بــه دلايـل

ايمنى سطح يرواز آنها به زمين نزديكتر است [1 ].

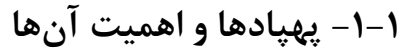

اين تجهيزات بهدليل اينكه قابليتهاى زيادى در اختيار

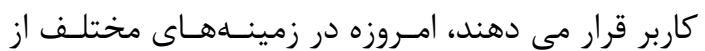
جمله جنگلـلهارى مورد توجه زياد قرار گرفتهانـد. انـواع مختلفى از سنجندههاى روى ايـن وسـايل قابـل نصـب بوده و با توجه به نياز كاربر به راحتى قابل تعـويض انـد.

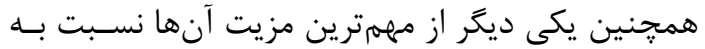

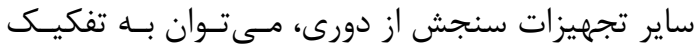
مكانى و زمانى قابل برنامهريزى توسط كاربر اشاره كـرد

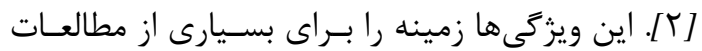
مختلف از جمله بيومترى، فنولـوزى، يـاتولوزى و غيـره

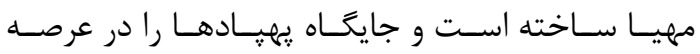
جنگل دارى بسيار كسترش داده اسـت. تصـاوير و دادههاى يهيْياد به دليل دارا بودن قابليت تبديل بـه تصـاوير سه بعدى، به محقق اين امكان را مىدهد تا بسـيارى از

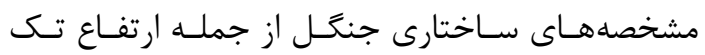

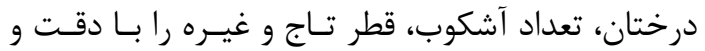
صحت بالا از تصاوير استخراج كند [ب].

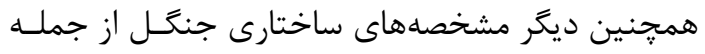

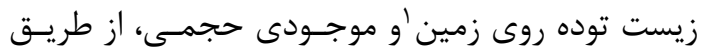

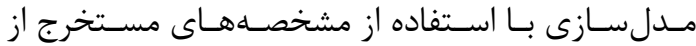
تصاوير سه بعدى قابل برآورد هستند [\&]. زيست تـوده روى زمين در واقع مقدار مواد زيستى حاصل ازفتوسنتز

${ }^{I}$ Above Ground Biomass 
سانتىمتر را داراست [V]. اين ويزَّى ها و توانـايىهـاى

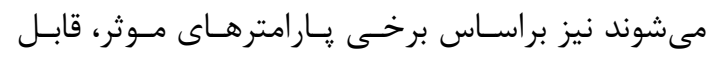

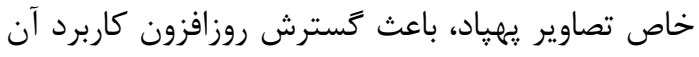

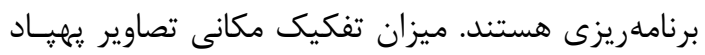

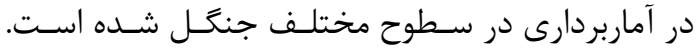
بسيار بالا است و توانايى تفكيـك قيديـدهــيـي بـانـا ابعـاد

\begin{tabular}{|c|c|c|c|}
\hline معايب & مزايا & روشهاى برداشت يارامترها & شيوههاى كلى \\
\hline 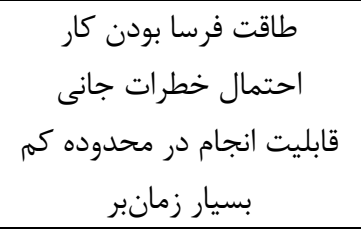 & 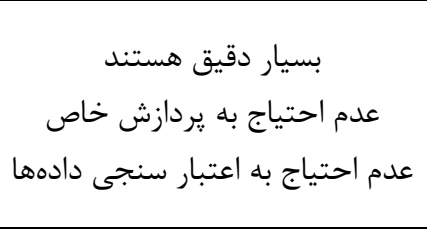 & 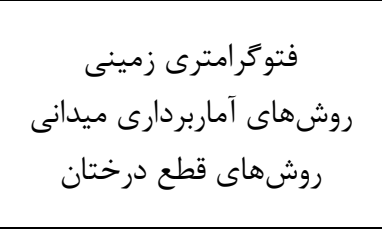 & $\begin{array}{l}\text { روشهاى زمينى (ميدانى) } \\
\text { رينى }\end{array}$ \\
\hline 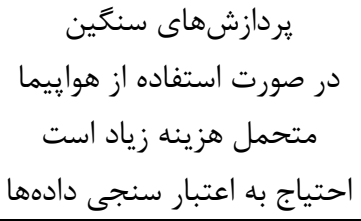 & قابليت انجام در محدوده متوسط & سنجندهنهاى لايدار & روش هاى هوابرد \\
\hline احتياج به اعتبار سنجى دادهنها & 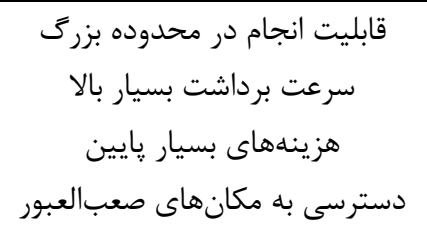 & استفاده از دادههاى ماهوارههاى & روشهاى فضابرد \\
\hline
\end{tabular}

rIWS

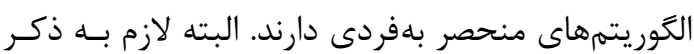
است كه آشكارسازى تك درختان در مناطق با يوشـش

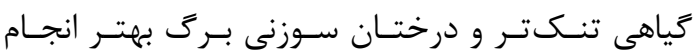

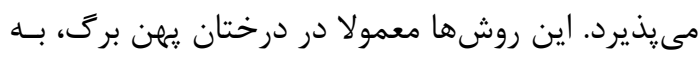

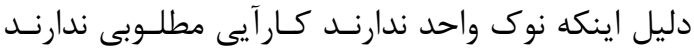

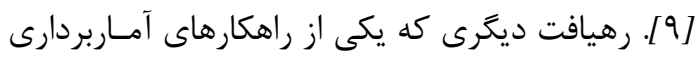

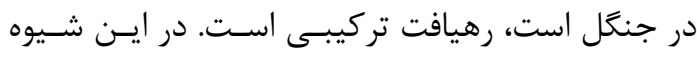

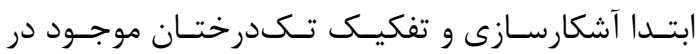

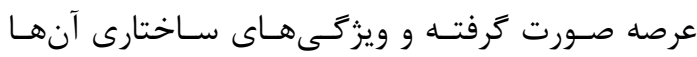

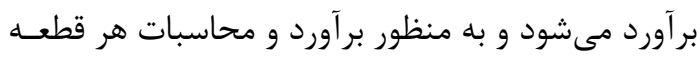

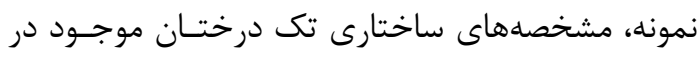

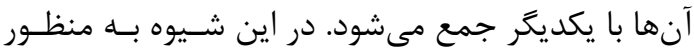

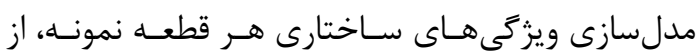

${ }^{2}$ Inverse Watershed Segmentation

${ }^{3}$ Local Maxima
1- ب- رهيافتهاى مختلف آماربردارى

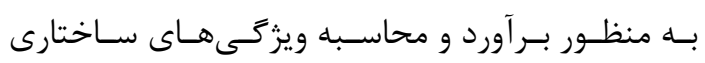
جنكَل، رهيافتهاى مختلفى ارائه شده كه آز آن جملـه مى توان به رهيافت تكدرختى و رهيافت تركيبى اشـاره

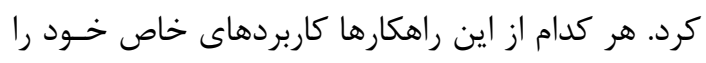

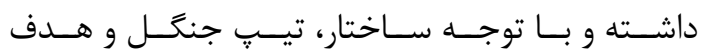
آماربردارى، انتخاب مىشود. بهدليل اينكـه در رهيافت

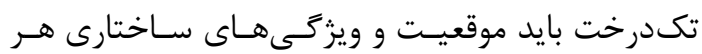

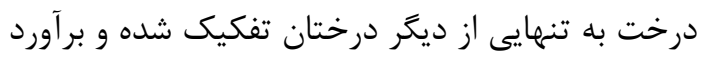

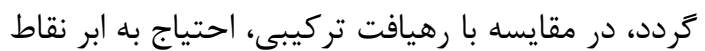

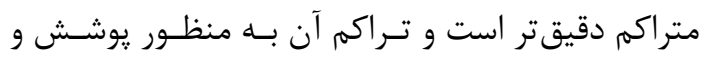

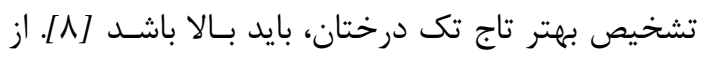

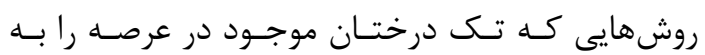

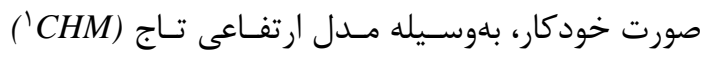
تشخيص داده و تفكيك مى كند، مى تــوان بــهـ الخَـوريتم

${ }^{I}$ Crown Height Model 
مربعات خطا نسبى • †, \& درصد زيست توده روى زمـين

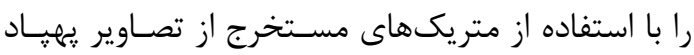

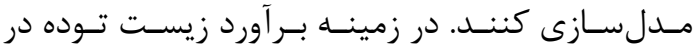
عرصههاى جنگلى با استفاده از شاخصهـاى سـاختارى مستخرج از تصاوير يهياد نيز تحقيقـاتى صـورت گرفتــه

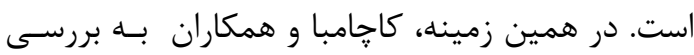

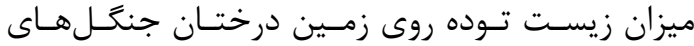

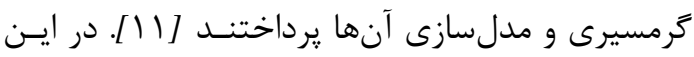

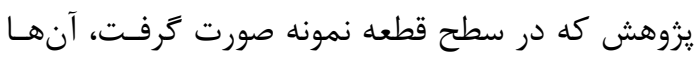
توانستند بـا مشخصـهـهـاى ارتفـاعى اسـتخراج شــده از

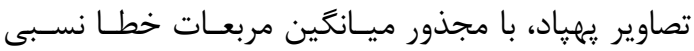
1 ر F\&,V

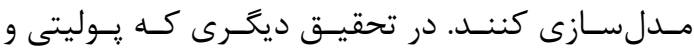
همكاران انجام دادند، به بررسى و مدلسازى موجـودى

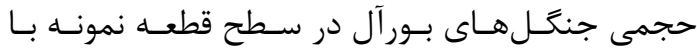

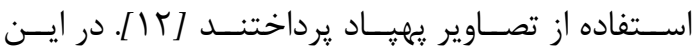
يزوهش آنها با استفاده از دادههاى ليزر اسـكنر هـوايى

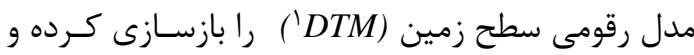

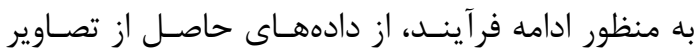
يهياد استفاده كردند. در اين يزوهش آنها توانسـتند بـا

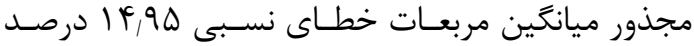
حجم توده را مدلسازى كنند. در يزوهشى كه جينى مربع و

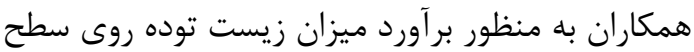
كياهان هيدروفيت در سطح تركيبى انجام دادند؛ آنهـا

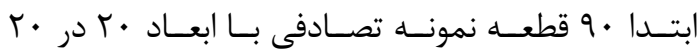
سانتيمتر طراحى كرده و سيس ارتفـاع تمـامى گَياهـان

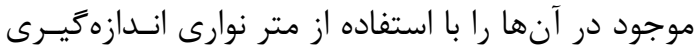
كردند؛ سيس به منظور برآورد مقدار دقيق زيست تـوده رهـ

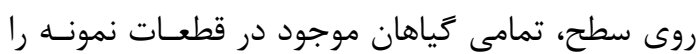

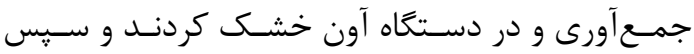

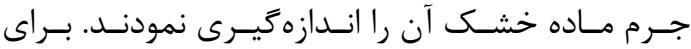

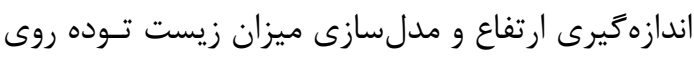

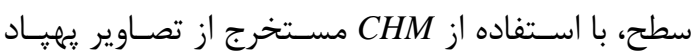

\footnotetext{
${ }^{1}$ Digital Terrain Model
}

مجموع مشخصههـاى تـك درختـان موجـود در آنهـا استفاده مىشود.

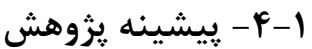

در زمينه برآورد زيست توده روى زمـين بــا اسـتفاده از

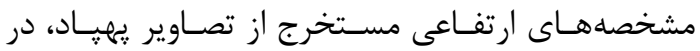
خارج از كشور تاكنون مطالعاتى صورت گرفته است. در اين زمينه مى توان به يزوهشى كه هرنانـدز و همكـاران

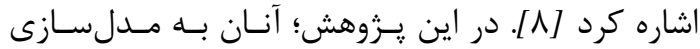

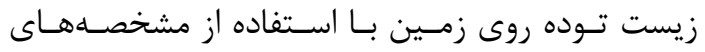

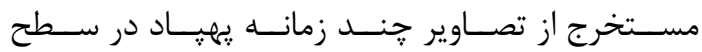

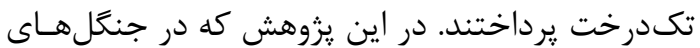

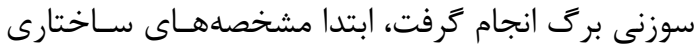

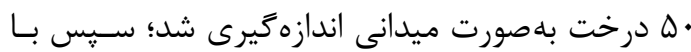
استفاده از ارتفاع بهدست آمده از تصـاوير يهيــاد كـه در

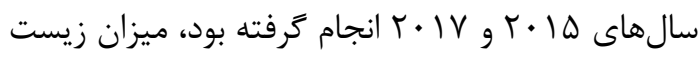
توده روى زمين تك درختان با مجذور ميانگين مربعات

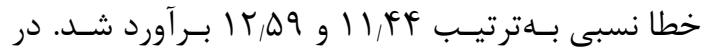
يزوهش ديخـرى كـه لـى و همكـاران در ســح قطعـه

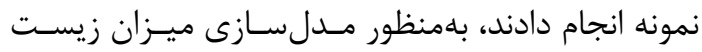
توده روى زمين تودههاى ذرّت در سطح قطعه نمونه، از متريكهاى مستخرج از CHM تصـاوير : يهيـاد اسـتفاده

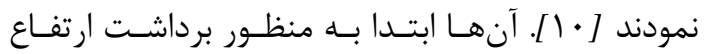

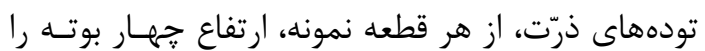

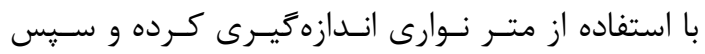
متوسط ارتفاع اين بوتهها را بهعنوان نماينده ارتفاع توده ثبت كردند. همهِنين آنهـا بــراى انـدازهزيـرى ميـزان زيست توده روى زمين، دو تا سه پايه از بوتههـاى ذرّت

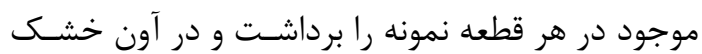

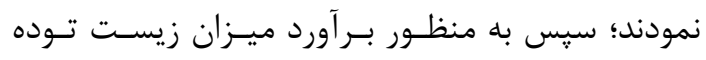
موجود در هر قطعه نمونه، وزن متوسط بوتههاى خشك بـ مرك شده هـر قطعــه نمونــه را در تـراكم آن ضـرب كـرده و

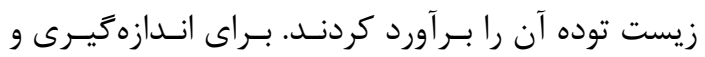
برداشت دادههاى هوايى نيز از يك يُهيـاد عمـود يــرواز

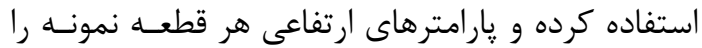

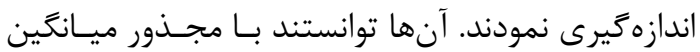




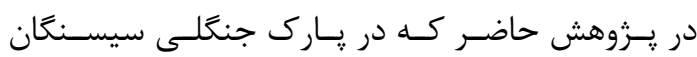

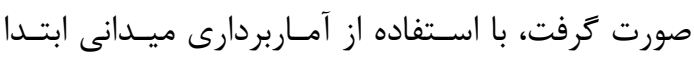
مشخصههاى ساختارى درختان ثبت شد. سيس زيست زيست توده روى زمين درختان در سه سطح تكدرخت، قطعه

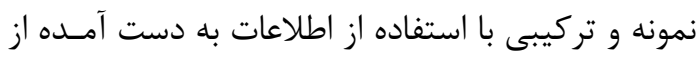

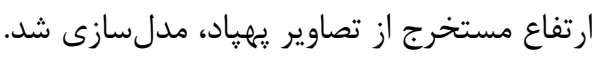

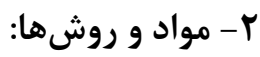
در ادامه مواد و روشها تشريح شده است.

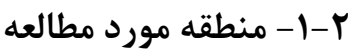

يارك جنكلى سيسنكان در كرانه جنوبى درياى خــز

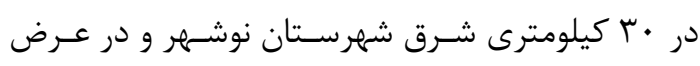

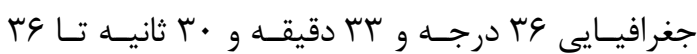

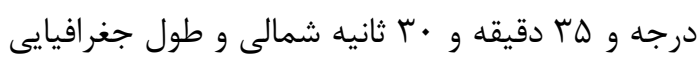

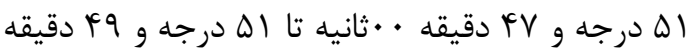

و • r ثانيه شرقى واقع شده است (شكل ( ) ().

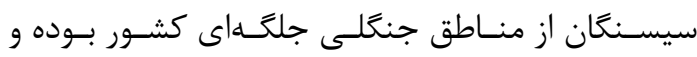

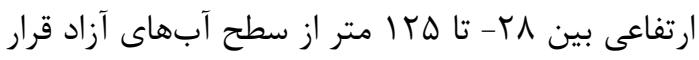

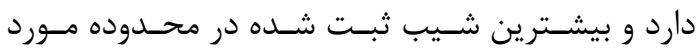

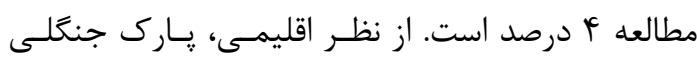

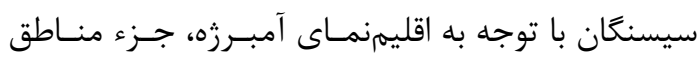
خيلى مرطوب با زمستان هاى ملايم و تـراكم درختـان

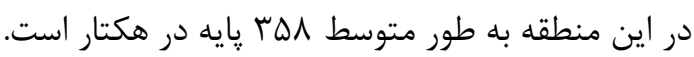

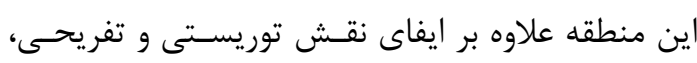

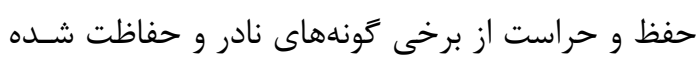

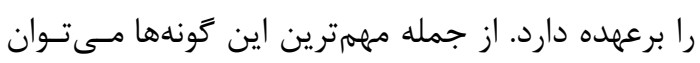

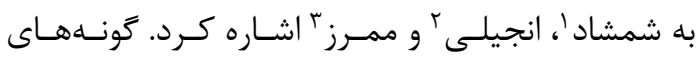

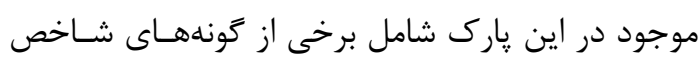

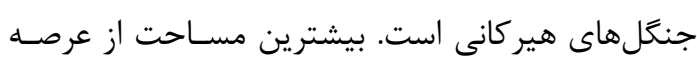

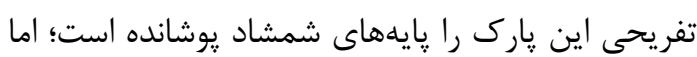

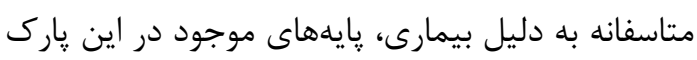

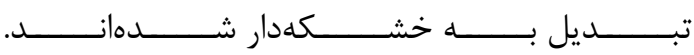

\footnotetext{
${ }^{1}$ Buxus hyrcana

${ }^{2}$ Parrotia persica

${ }^{3}$ Carpinus betulus
}

عمود يرواز، ارتفاع كياهان موجـود در قطعـات نمونـهـ را

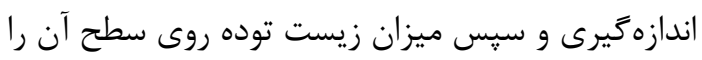

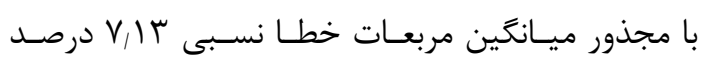
مدل سازى كردند [با إ].

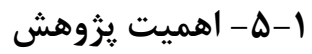

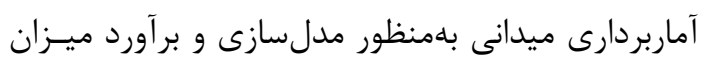

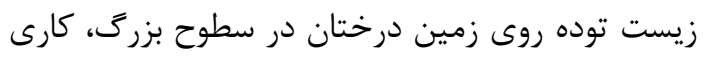

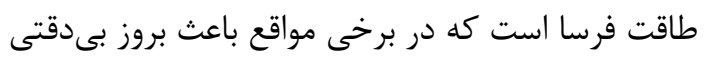

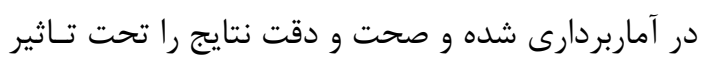

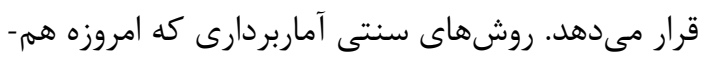

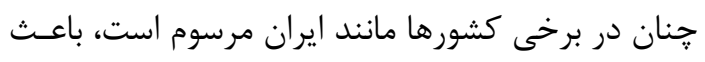

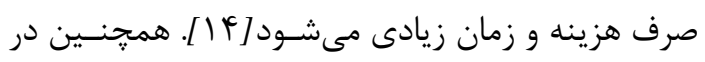

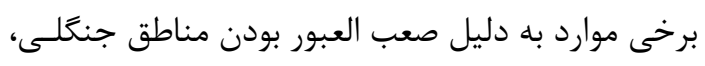

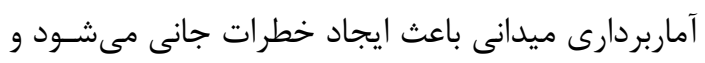

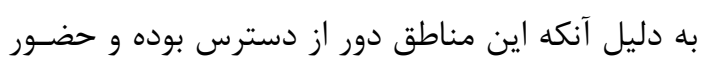

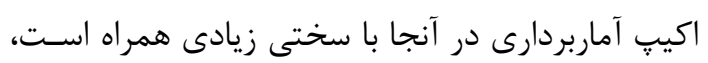

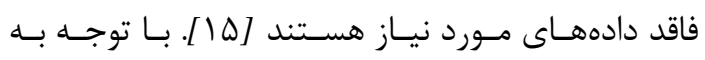

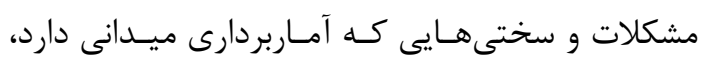

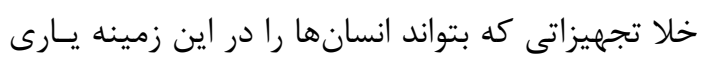

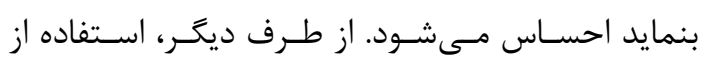

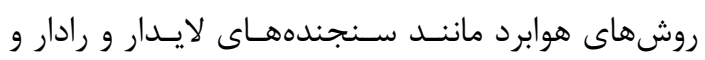

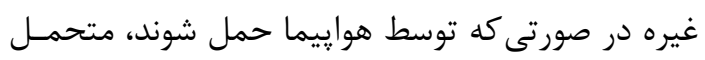

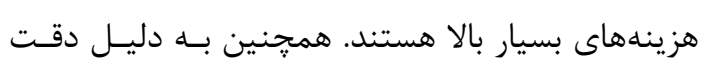

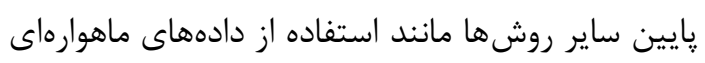

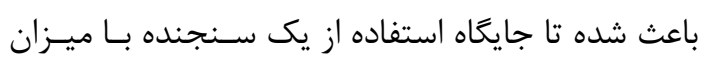

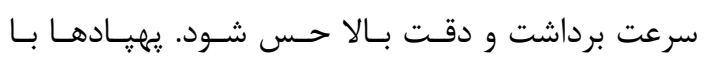

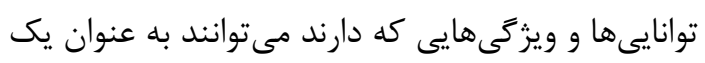

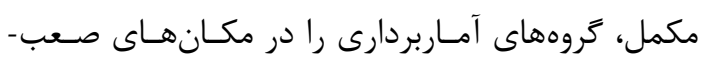

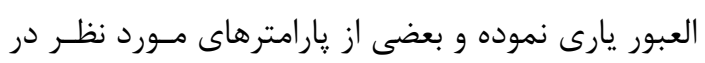

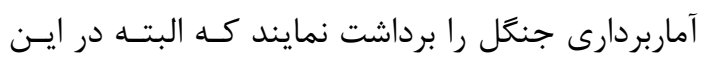

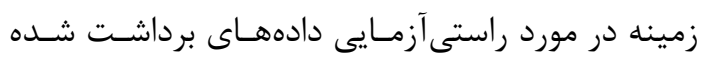

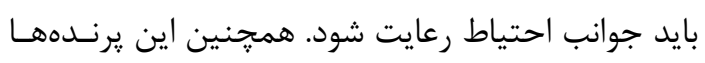

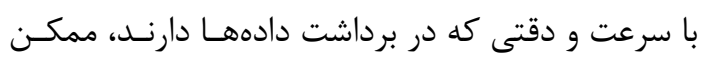

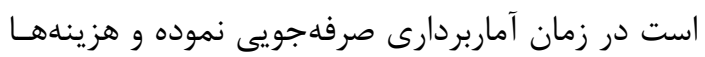
را كاهش دهند. 


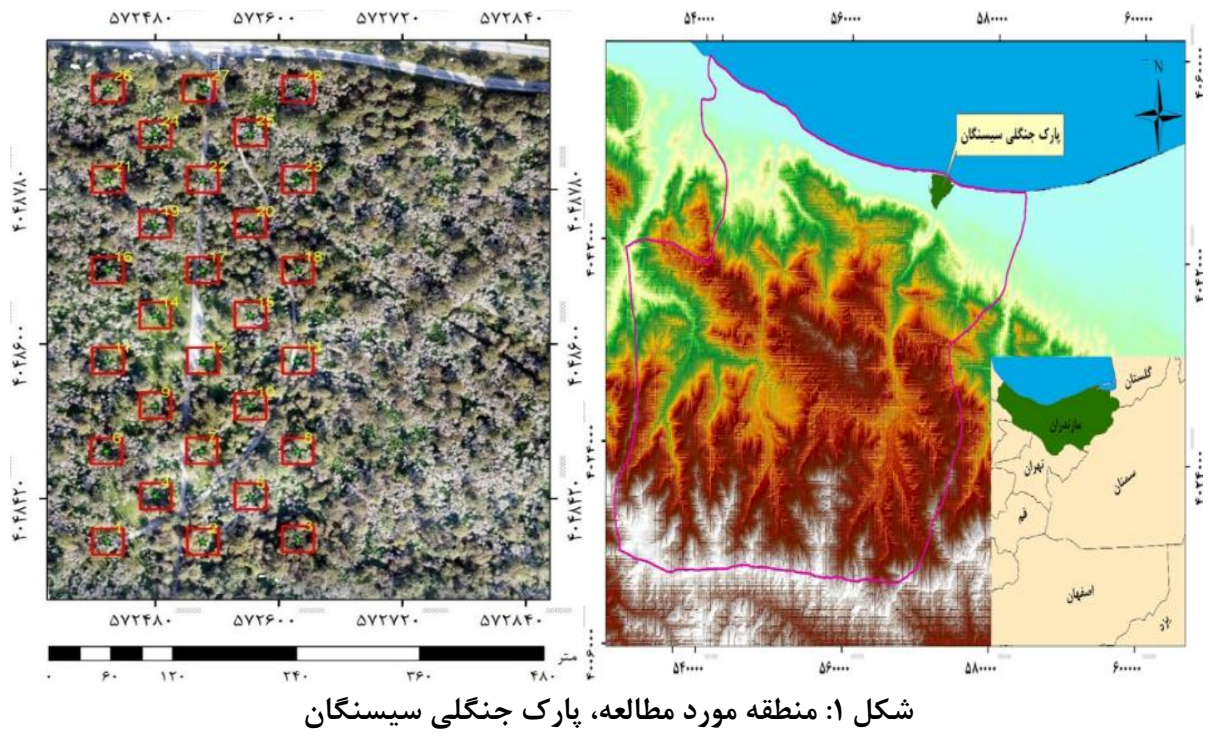

مسير يـروازى طراحسى شــه بـهـوسـيله نـرمافـزار كــه

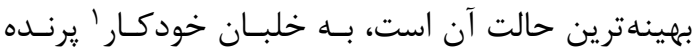
ارسال شـد و عمليـات برداشـت بـه صـورت اتوماتيـك تهـ

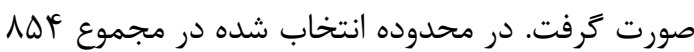
تصوير برداشـت شـد. ارتفــاع يـرواز · ا متــر و فاصـله

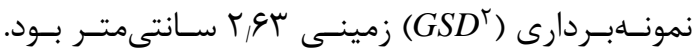

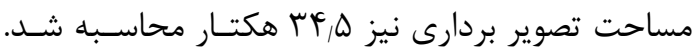

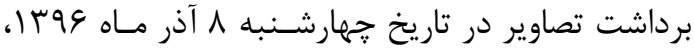

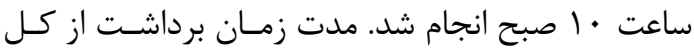

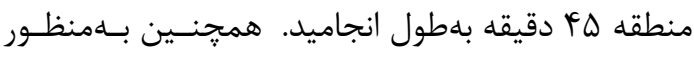

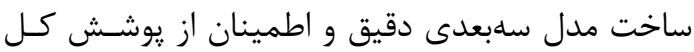
9نطقه مـورد مطالعـه، ميـزان هـميوشـانى تصـاوير

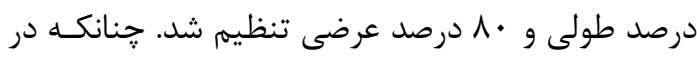

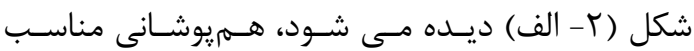

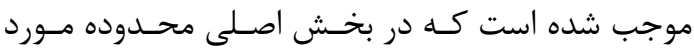

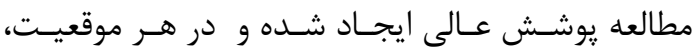
حداقل بيش از 9 تصوير ديده شود.

\footnotetext{
${ }^{1}$ Autopilot

${ }^{2}$ Ground Sample Distance
}

r-r - تصوير بردارى هوايى

در اين مطالعه بهمنظور برداشت تصاوير هـوايى از يـك

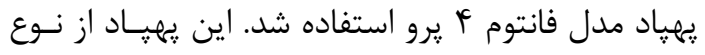

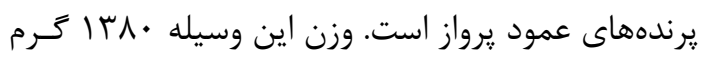

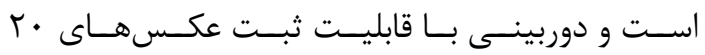
مخاييكسلى را با خود حمل مسى كنــد. ابعـاد هركـدام از

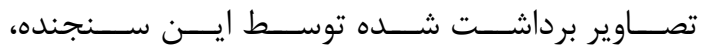

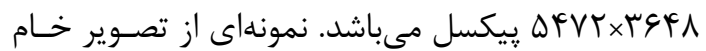
برداشت شده توسـط ايسن سـنجنده در شـكل (r- ب)

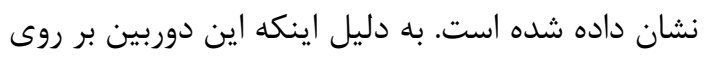
يك لرزش گير بسيار قوى سهمحوره نصـب شـده اسـت، هيجزَّنه لرزش و اعوجاجى در تصاوير ديده نمسىشـود. مسير يروازى يهياد و مكانهايى كه بايسـد تصـويربردارى صورت كيرد، قبل از انجام يرواز مشخص شد. اين كار از

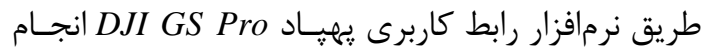

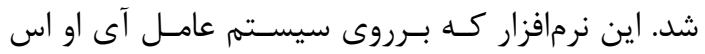

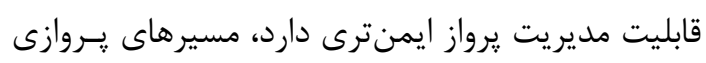

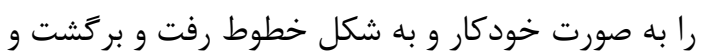
با توجه بـ پارامترهاى مورد نياز كاربر طراحى مسى كنـد. 


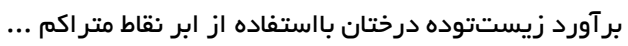

محمدرضا كاركر، هرمز سهرابى
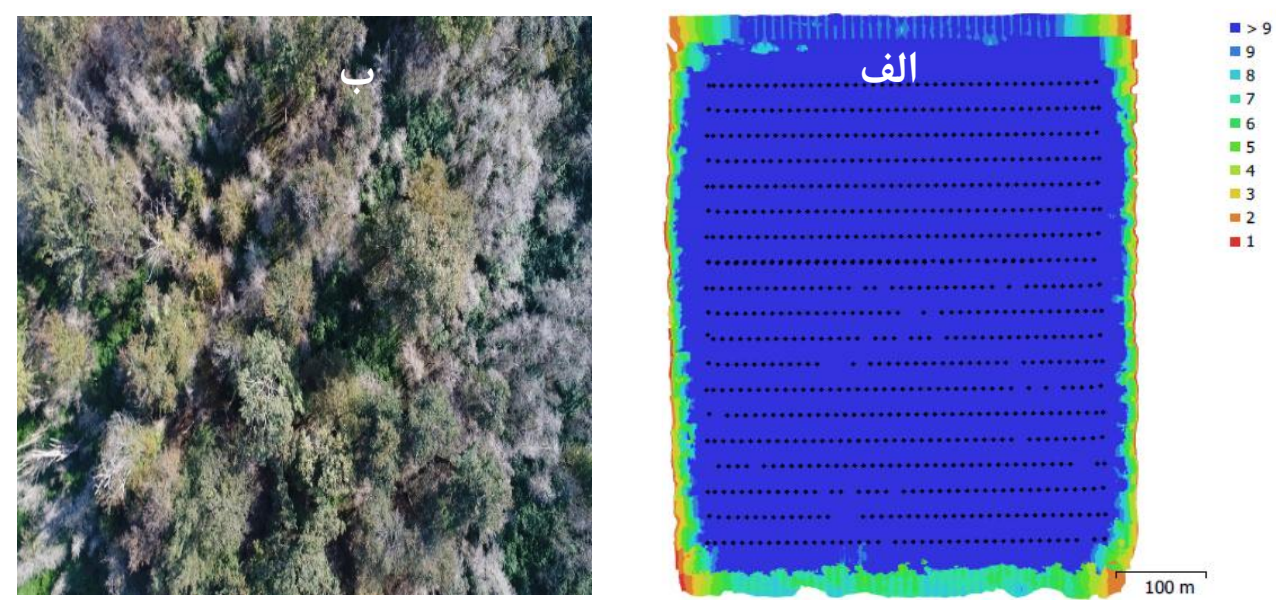

شكل r: الف: ميزان هميوشانى تصاوير برداشت شده نسبت به مراكز تصويربردارى ب: تصوير خام برداشت شده توسط سنجنده يهياد فانتوم f يرو

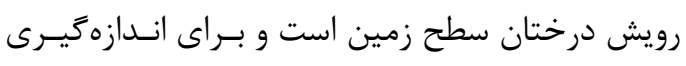

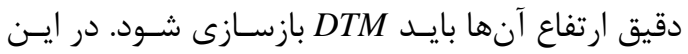
يزوهش به منظور ساخت DTM، با استفاده از فيلتر ابر نقاط با يك ينجره r مترى با شرط حسد ماكثر تغييـرات

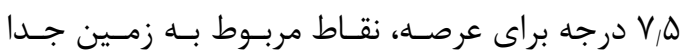

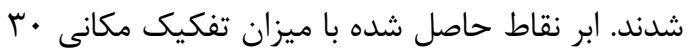
سانتىمتر در هر ريكسل به فايل رسترى تبـديل شـد.

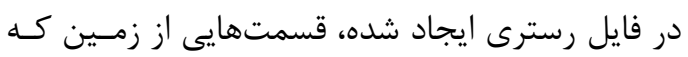

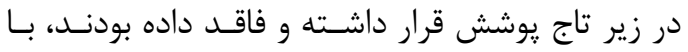

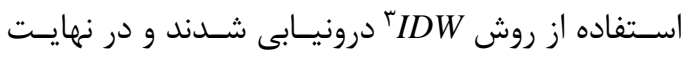
DTM روش IDW بـهـ ايسن دليـل بـود كـهـ از آن بـهـ منظــور

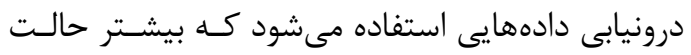

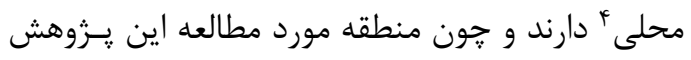

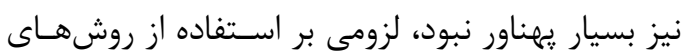

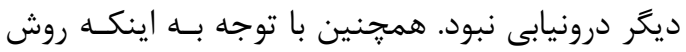

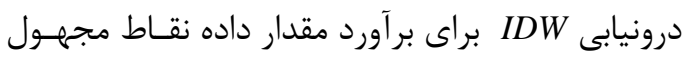

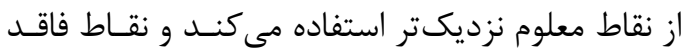
داده اين يزوهش نيز كه نقاط ارتفاعى بودند، هر كـدام

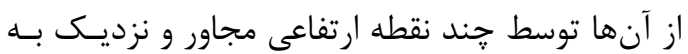

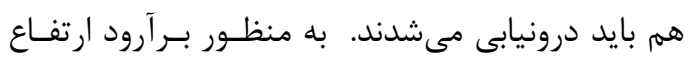

\footnotetext{
${ }^{3}$ Inverse Distance Weight

${ }^{4}$ Local
}

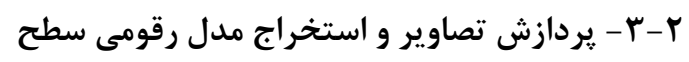
در طول تصويربردارى هوايى، موقعيت جغرافيـايى هـر

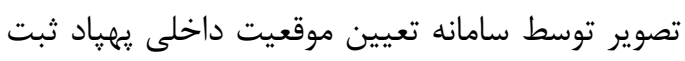
شد و به تصاوير الحاق مىشود. يس از انتقـال تصـاوير

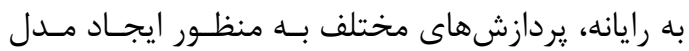

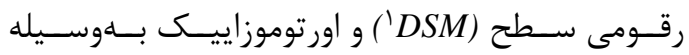

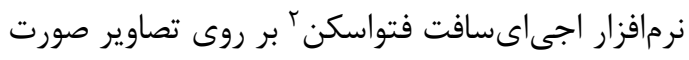
كرفت. يس از مرتب شدن تصاوير در كنار يكـديخر، بـا

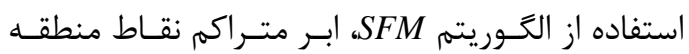

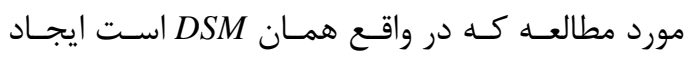

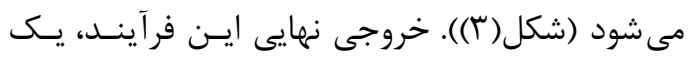

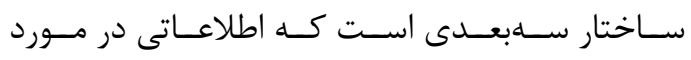

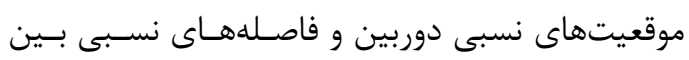
دوربين و شى نيز ارائه مي دهد. در نهايت با اسـتفاده از

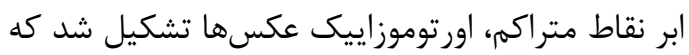

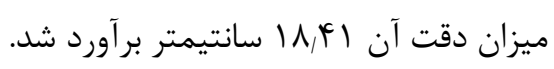
r

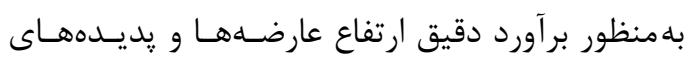
موجود در منطقه مورد مطالعه، محــل قراركيــى و يــا

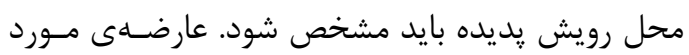

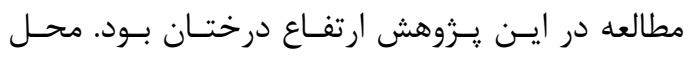

\footnotetext{
${ }^{1}$ Digital Surface Model

${ }^{2}$ Agisoft PhotoScan
} 


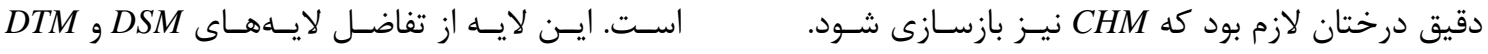

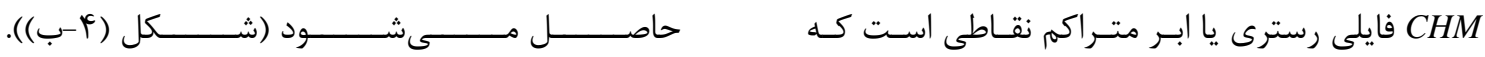

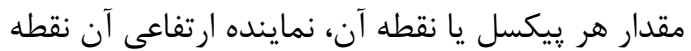
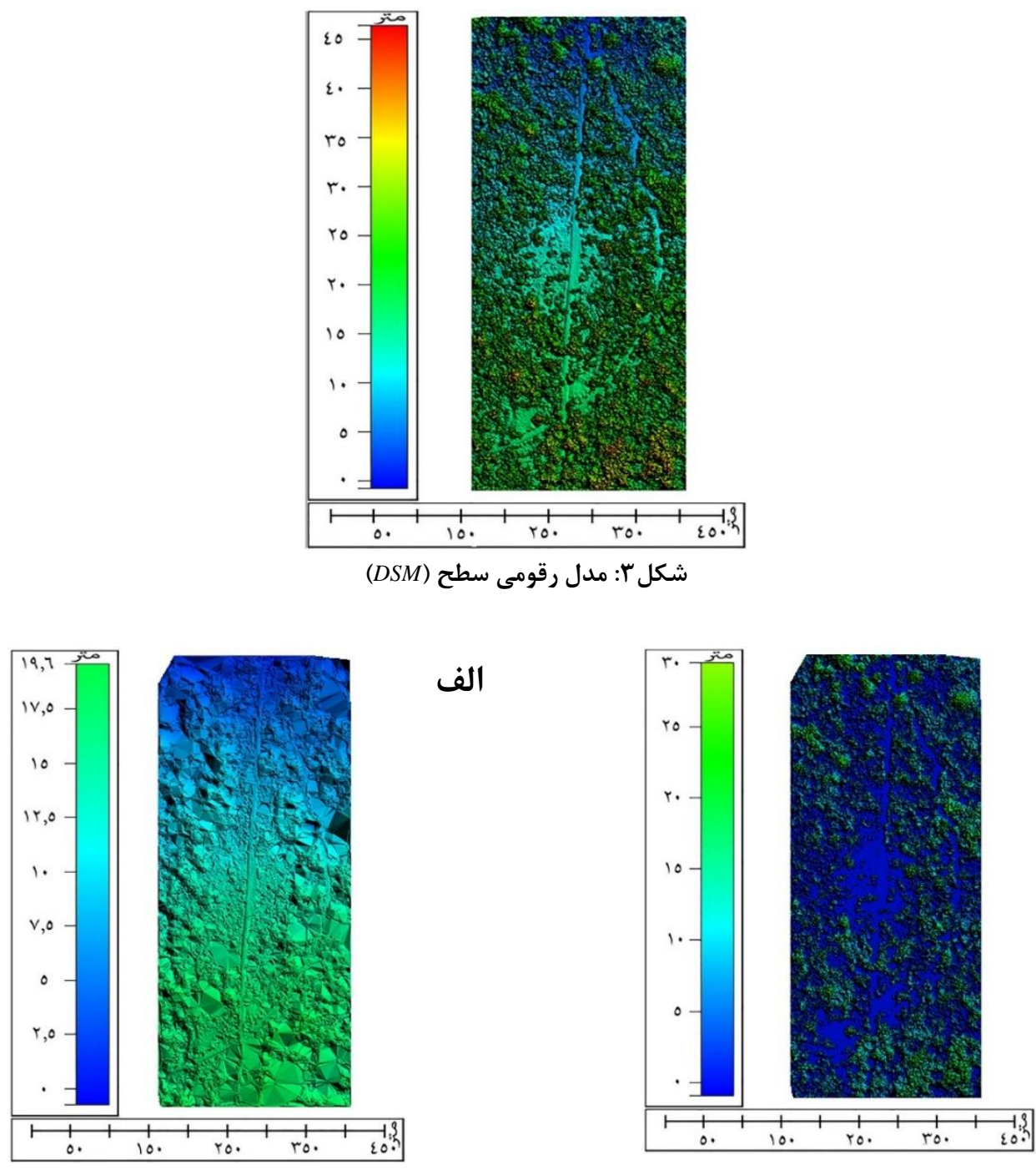

شكل F: الف: مدل رقومى سطح زمين (DTM)، ب: مدل ارتفاعى تاج (CHM) 
برآورد زيستتوده درختان بااستفاده از ابر نقاط متر اكم ...

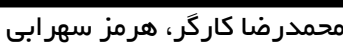

r-צ- محاسبه مقدار واقعى و بر آورد زيست توده

روى زمين

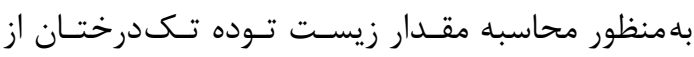

رابطه آلومتريك عمومى زيست توده استفاده شد.

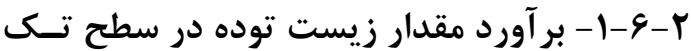

درخت

رابطه آلومتريك عمومى زيست توده (رابطه ( ()) از قطر

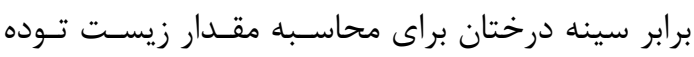
روى زمين استفاده مى كند.

$A G B=0.3 D B H^{2.33}$

(1)

كه در آن، AGB زيست توده روى زمين درخت و DBH

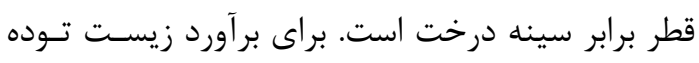

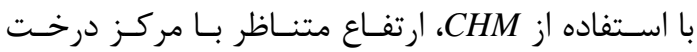

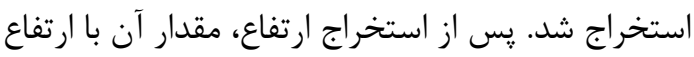

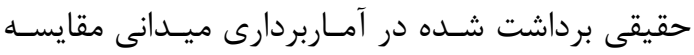

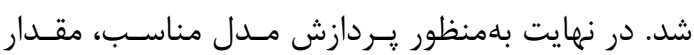
زيست توده واقعى بهعنوان متغير وابسته و مقدار ارتفاع

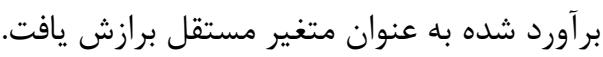

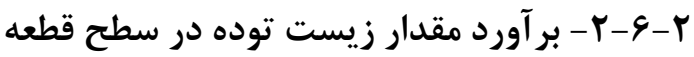

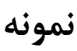

براى مدلسازى زيست توده درختان در رهيافت قطعـهـ نمونه، ابتدا مجموع زيسـت تـوده واقعى تـكـدرختـان موجود در هر قطعه نمونه بهعنوان زيست توده آن قطعه ندان

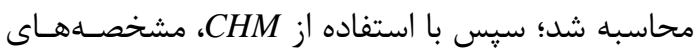

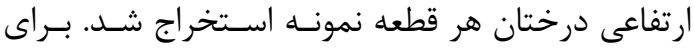

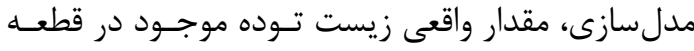

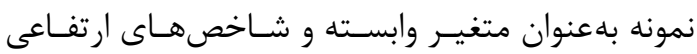
بهعنوان متغير مستقل مدلسازى شدند. در اين سـطح، فقط رابطه بين شاخصهاى ارتفاعى (جارك هان، دهك إنها،

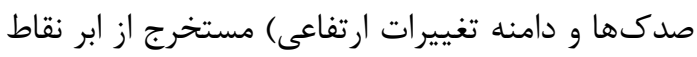

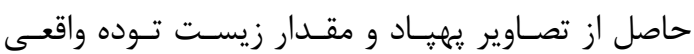
بررسى و مدل سازى شد. لازم به ذكر است كـه در ايـن سطح بهمنظور مدلسازى ميزان زيست توده روى زمين

\section{r- - شيوه نمونهبردارى ميدانى}

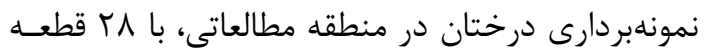

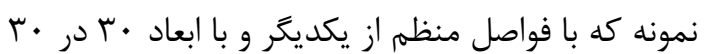

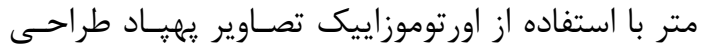
شد. بلمنظور يِيادهسازى در عرصه، هر كـدام از قطعـات

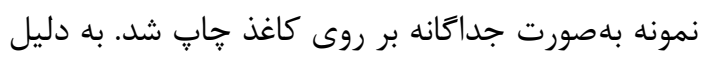

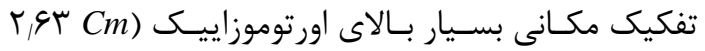
(GSD ) קاب شده، جانمايى قطعات در عرصه آسان بـود.

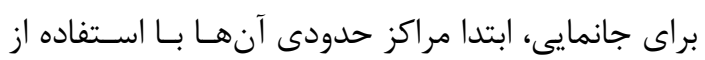

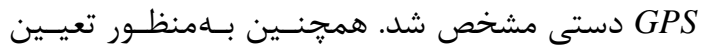

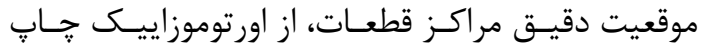

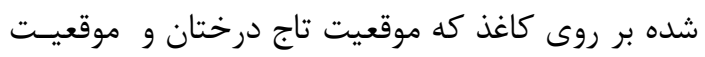

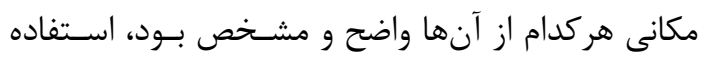

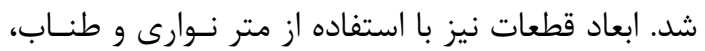

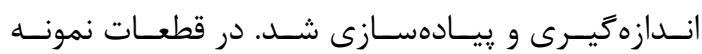

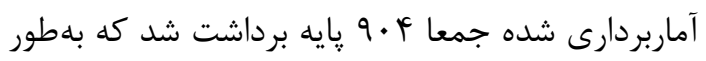

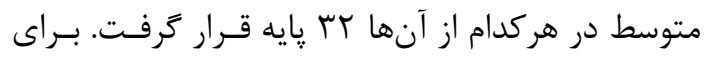
اندازهگيرى ارتفاع درختان موجود در قطعات نمونه لازم

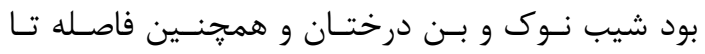

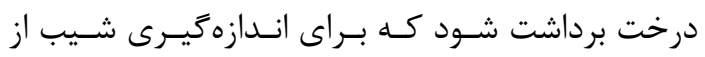

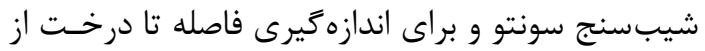

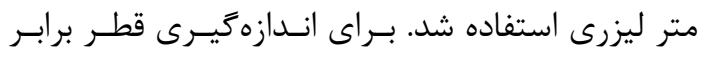

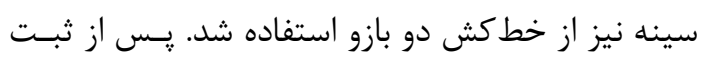

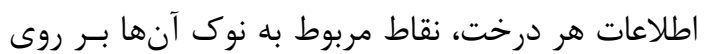

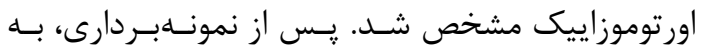

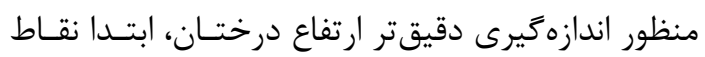

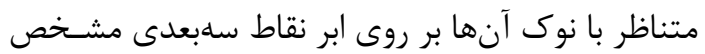

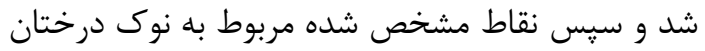

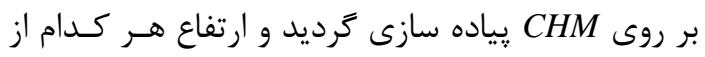
آنها استخراج شد. لازم به ذكر است كه اين كار باعث

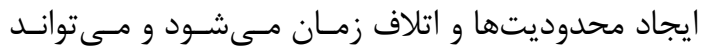

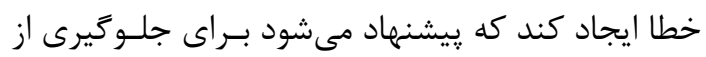

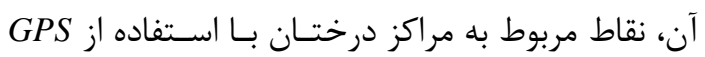

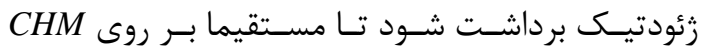
ييادهسازى شده و ارتفاع اندازهخيرى شود. 
يكـديكر مقايسـه شــند كـه در شـكل (9) نتـايج ايـن

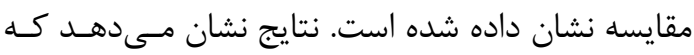

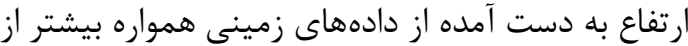
ارتفاع محاسبه شده بر اساس CHM است.

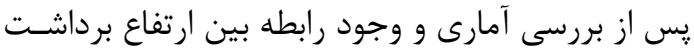

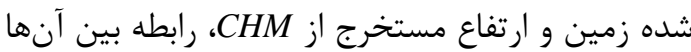

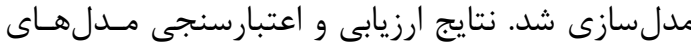
ركرسيونى برازش يافته در جدول (Y) ذكر شده است.
درختــان بـا اسـتفاده از دادهــاى مسـتخرج از تصـاوير يهياد، مىتوان از قطر تاج درختان نيز استفاده نمود.

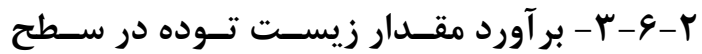
تركيبى

براى مدل سازى در اين سطح ابتدا مقدار زيست توده بـاــا

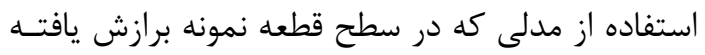

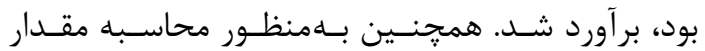
زيست توده واقعى، از مجموع زيست توده مشاهده شده تك درختان موجود در هر قطعـه نمونـهـ اسـتفاده شـد.

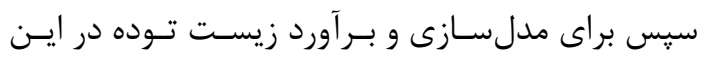

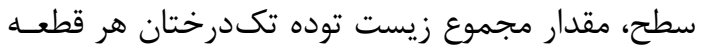

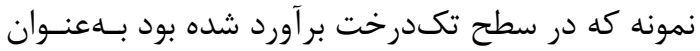

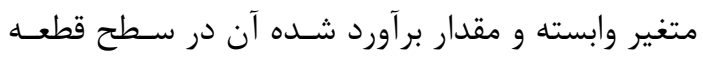
نمونه باعنوان متغير مستقل مدلسازى شدند.

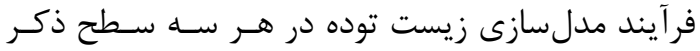
شده در شكل (ه) نشان داده شده است. r-V- روش ارزيابى نتايج براى بررسى صحت و دقـت بــرآورد ارتفـاع درختـان، از جذر ميانكَين مربعات خطاى نسبى (رابطه (؟))، اريبى نسبى (رابطه (ץ)) و ضريب تبيين تطابق يافته اسـتفاده شد. مدل هاى ركرسيونى براساس VD در درصد مشـاهدات

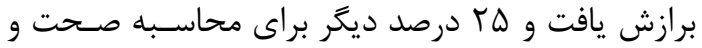

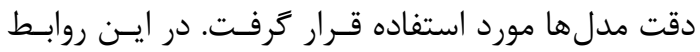
RMSE ميانكين مقادير واقعى متغير وابسته است. رابطه Bias $_{r}=\frac{\text { Bias }}{\bar{y}} \times 100 \quad$ رابطه(ب) در ادامه هر مورد به تفصيل شرح داده شده است. r- ا- نتايج مدلسازى ارتفاع درختان:

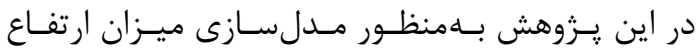

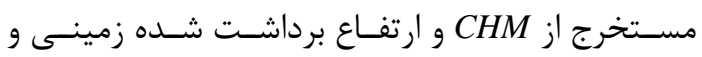

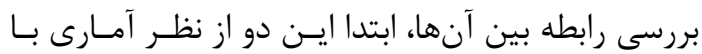


برآورد زيستتوده درختان باستفاده از ابر نقاط متر اكم ...

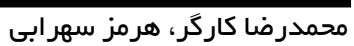

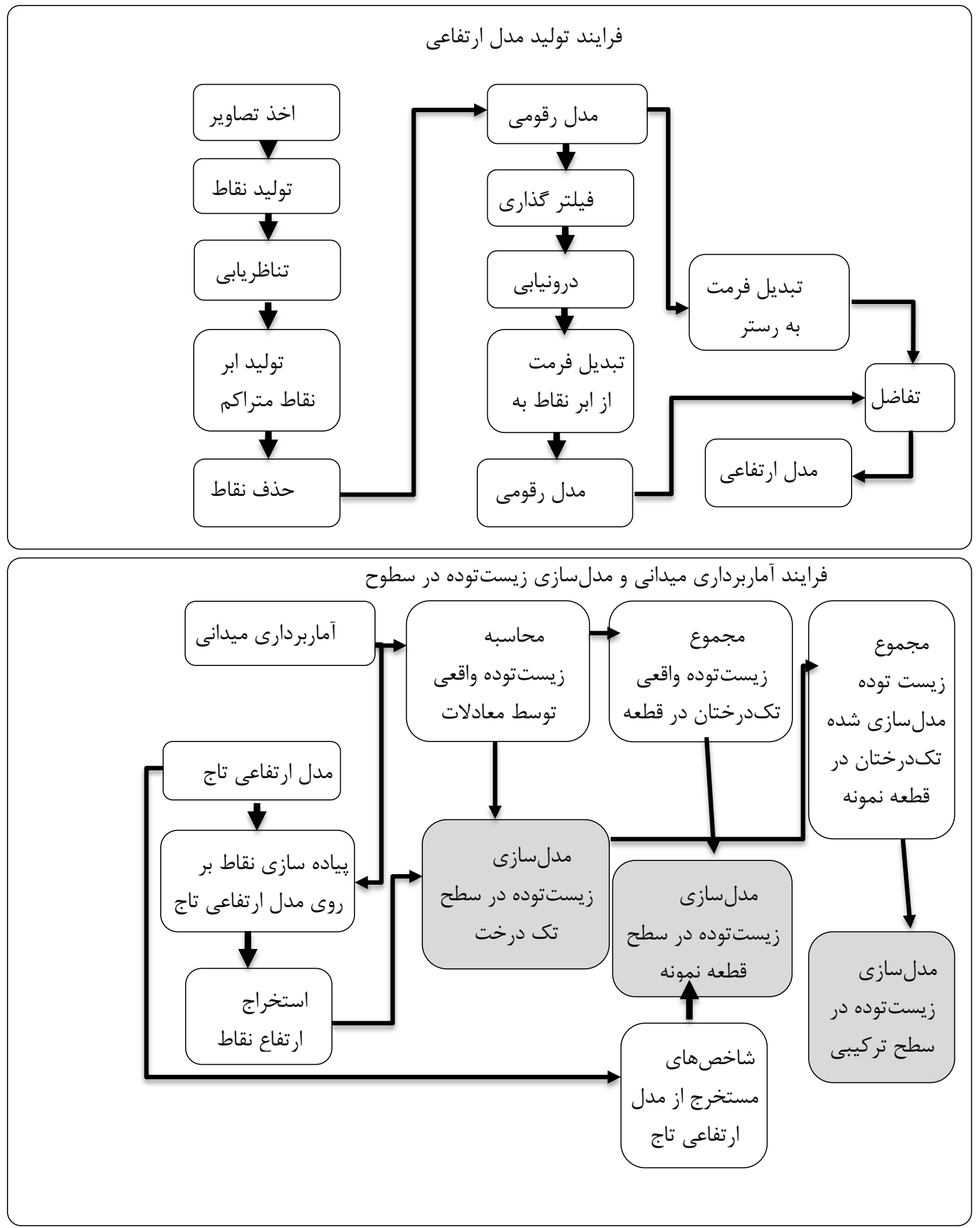

شكل ه: فر آيند توليد مدل ارتفاعى تاج درختان و مدلسازى زيست توده در سطوح مختلف 


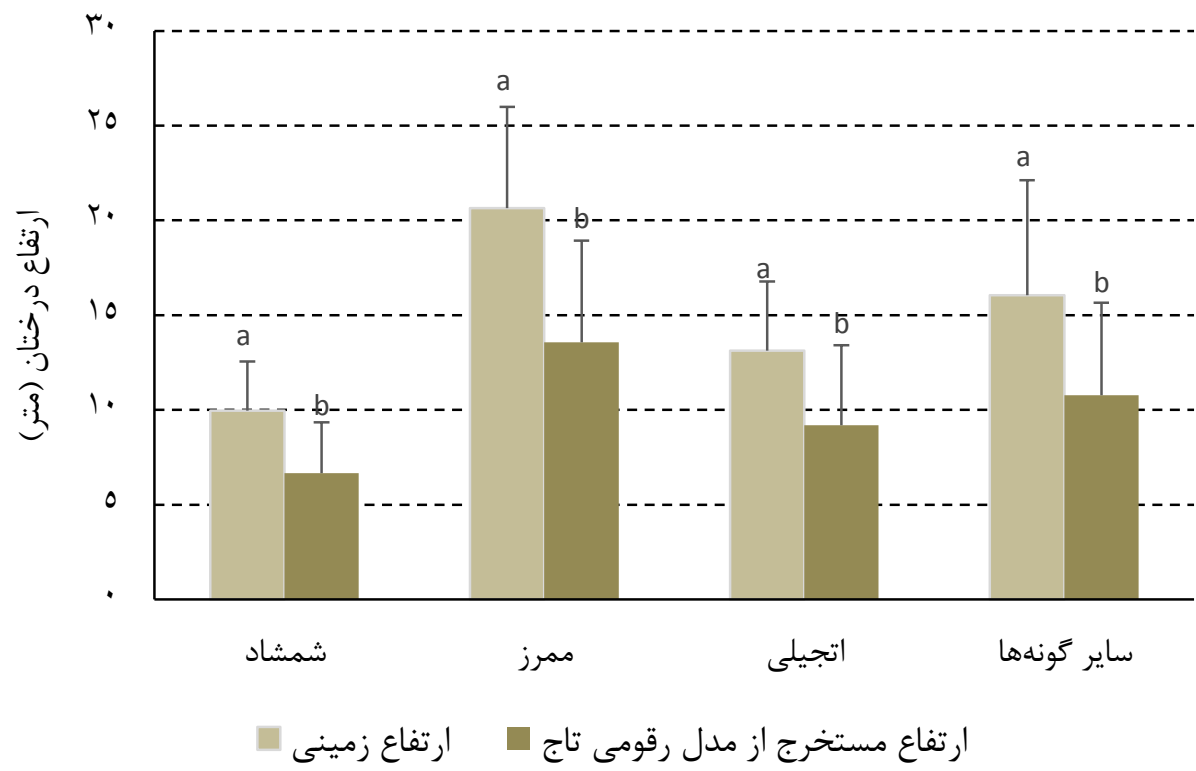

شكل 9: مقايسه ارتفاع برداشت شده زمينى و ارتفاع مستخرج از CHM، اعداد متفاوت بر روى دو ستون مجاور نشاندهنده

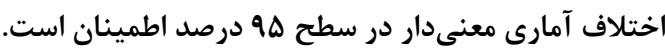

جدول r: ارزيابى مدلسازى ارتفاع زمينى و ارتفاع مستخرج از CHM

\begin{tabular}{|c|c|c|c|c|}
\hline اريبى نسبى & اريبى - اري & مجذور ميانگين مربعات خطا نسبى & مجذور ميانگين مربعات خطا & كونهها \\
\hline$\cdot 11$ & $\cdot . \cdot r$ & $r \cdot r q q$ & $r_{1} \cdot \Delta$ & شمشاد \\
\hline $9, \pi 1$ & 1,91 & $r \cdot r q q$ & 5,11 & 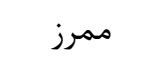 \\
\hline$V, q$. & 1,11 & $r \cdot \Delta V$ & $r, 19$ & 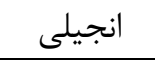 \\
\hline$\Delta, 9 \Delta$ & $\cdot \wedge \Delta$ & $r q / \Delta r$ & $F, r)$ & ساير گونهها \\
\hline
\end{tabular}

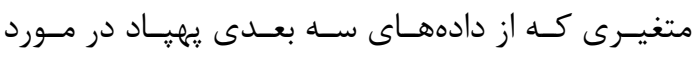
درختان در اين تحقيق استخراج شد، ارتفاع تـوده بــود. در حاليكه برآورد زيست توده بر مبناى قطر برابر سـينه است و ارتباط قطر برابر سينه و ارتفاع درختان به دليل

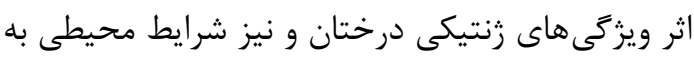
شدت متغير بوده و خود يكى از عدم قطعيتهايى است

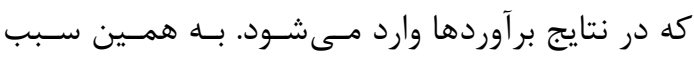

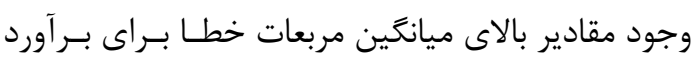
زيست توده قابل انتظار است. از طرف ديخر به توجه به معمارى درخت، ممـرز شـكل

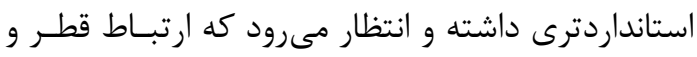

r-r- نتايج مدلسازى زيست توده روى زمين در سطح تك درخت نتايج ارزيابى مدلسازى و بــرآورد ميـزان زيسـت تـوده روى زمين تك درختان با استفاده از ارتفاع مستخرج از در جدول (Y) ذكر شده است. براى تمام گونههـا

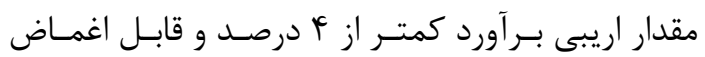

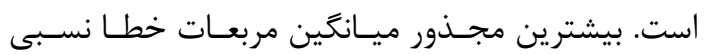

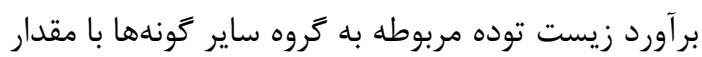

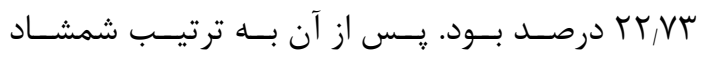

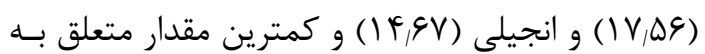

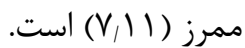


برآورد زيستتوده درختان بااستفاده از ابر نقاط متراكم ...

محمدرضا كاركر، هرمز سهرابى

اندك اين گَونها براى تحليل) اثر ناهمكنى ارتباط قطر

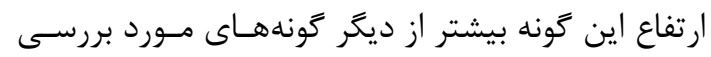

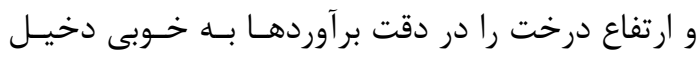

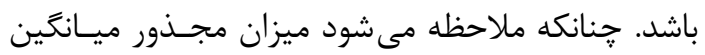

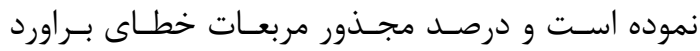
مربعات خطاى برآورد زيست توده براى اين كونه كمتر

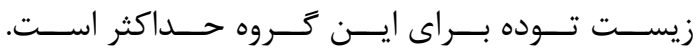

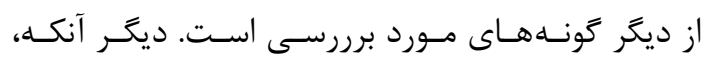

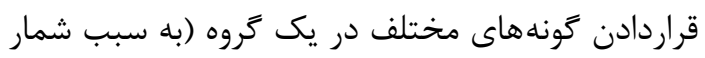

\begin{tabular}{|c|c|c|c|c|}
\hline اريبى نسبى & 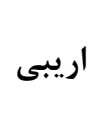 & مجذور ميانغين مربعات خطا & مجذور ميانكين مربعات خطا & 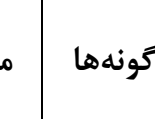 \\
\hline$\cdot \cdot \wedge$ & $\cdot, \cdot$ & $\mid V / \Delta \varphi$ & תז, & شمشاد \\
\hline$r, \wedge V$ & • & $\mathrm{V}, 11$ & $\cdot$ TF & ممرز \\
\hline$-1, \cdot 9$ & $-\cdot \cdot \cdot r$ & $\mid f, \& V$ & $\cdot, \mu^{c}$ & انجيلى \\
\hline$-1 \cdot$ VG & $-\cdot, \Gamma \varphi$ & $r$ r, RT & $\cdot \Delta F$ & ساير گَونهها \\
\hline$-T, V T$ & $-\cdot \cdot \cdot \Delta$ & $\mid f, \lambda F$ & $\cdot \pi \Lambda$ & كل گونهها \\
\hline
\end{tabular}

از متغيرهاى دامنه تغييرات مقادير مدل ارتفاعى تاج در

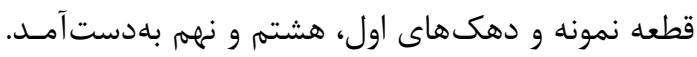
r-r- نتايج مدلسازى زيست توده روى زمين در سطح قطعه نمونه

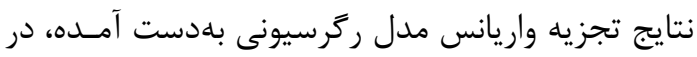
جدول (ه) كزارش شــده اسـت. بــر اسـاس ايـن نتـايج،

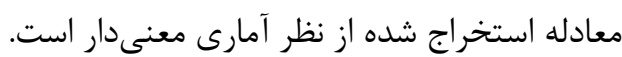

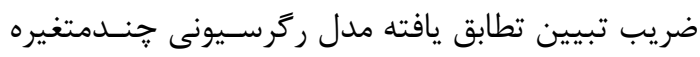

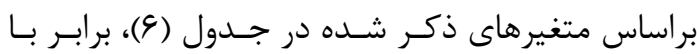

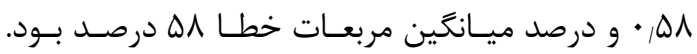

جدول f: ضرايب برآورد شده مدل برازش يافته ميزان زيست توده در سطح قطعه نمونه

\begin{tabular}{|c|c|c|c|c|}
\hline$p$-value & 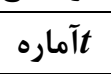 & خطاى استاندارد & ضريب ل & متغير هاى وارد شده در مدل \\
\hline.,$\cdot \operatorname{lr}$ & $r, 8 \Lambda$ & 19,99 & rrq, v. & عرض از مبدا \\
\hline$\cdot . \cdot \Delta \Delta$ & - T,ET & 9,49 & $-M F, M q$ & دامنه \\
\hline$<\cdots 1$ & $0, \cdot 9$ & 11,19 & $9 r, 99$ & دهك اول \\
\hline. $.111 \mathrm{~F}$ & $-r, V \Delta$ & $r \cdot \wedge 9$ & $-\lambda F, 9 \Lambda$ & دهك هشتم \\
\hline. .194 & $r, \Delta r$ & $r \Delta, v r$ & $\wedge 9,9$. & دهك نهم \\
\hline
\end{tabular}


جدول ه تجزيه واريانس مدل برازش يافته ميزان زيست توده در سطح قطعه نمونه

\begin{tabular}{|c|c|c|c|c|c|}
\hline$p$-value & Fاره Fارم & ميانكَين مربعات & مجموع مربعات & درجه آزادى & منبع تغييرات \\
\hline \multirow{3}{*}{$\cdot \cdots r$} & 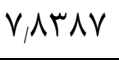 & $\wedge \wedge \Delta \backslash \Lambda, 1$ & $r \Delta r \cdot V r, \Delta l$ & f & مدل \\
\hline & & $\| r q r, \Delta$ & 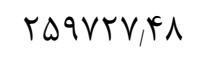 & rץ & خطا \\
\hline & & & 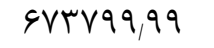 & tr & مجموع \\
\hline
\end{tabular}

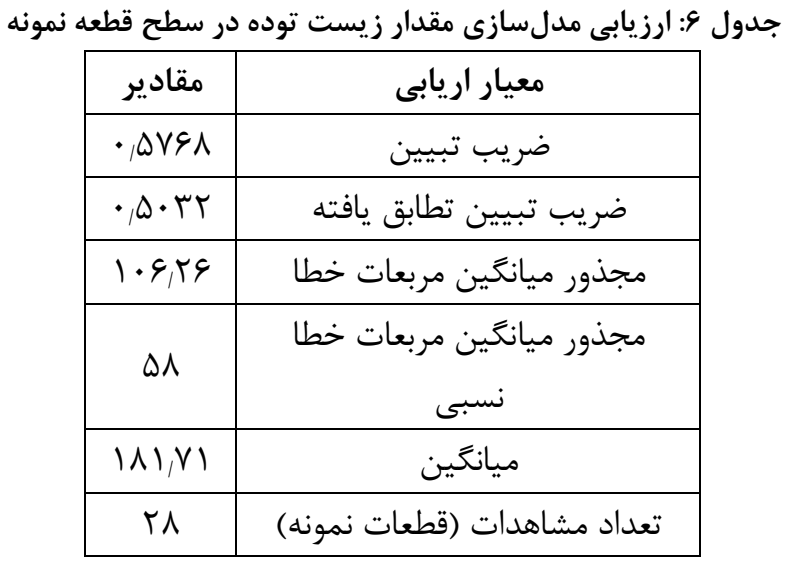

مطالعه انتخاب مىشود؛ هر جقدر منطقه تنكىتر باشـد،

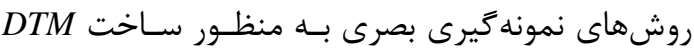

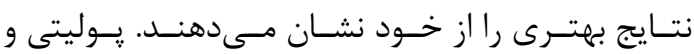

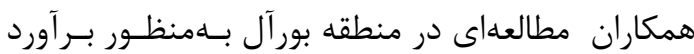

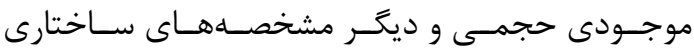

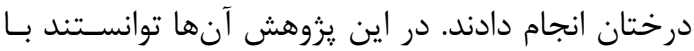

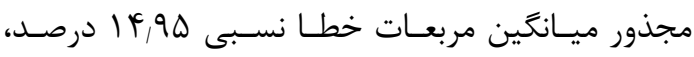

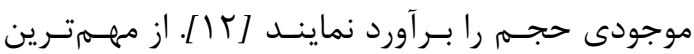

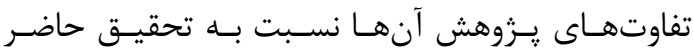

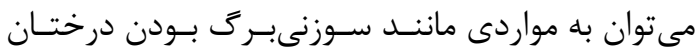

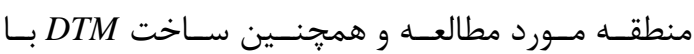

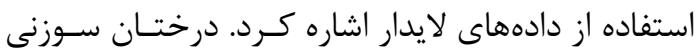

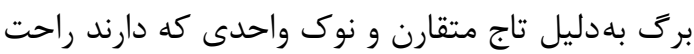

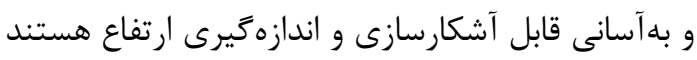

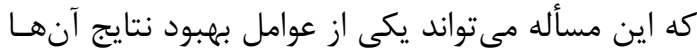

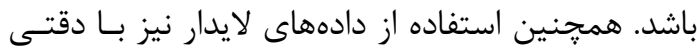

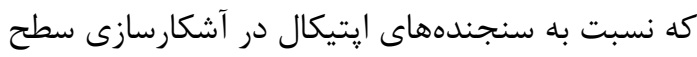
زمين دارند، در امر بهبود نتايج موثر است. همجنين در

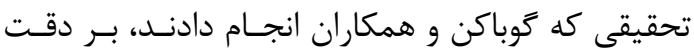

با توجه به مطالعات متعددى كه در اين زمينــه صـورت كرفته است، عوامل كاهش دقت مــل را مسى تـوان در موارد مختلفى جستوجو كـرد. سـاختار و نــوع جنَــل

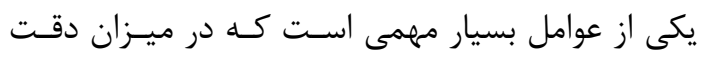
مدل موثر مـى باشـــ در همـين زمينــه، مطالعـهاى كـهـ

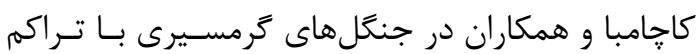
يايين انجام دادند، با استفاده از بيشينه ارتفاع مستخرج از CHM، ميزان زيست توده را مدلسازى كردند[ [I]"] ميزان مجذور ميانگين مربعات خطا نسبى اين يـرزوهش

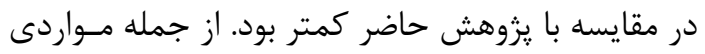

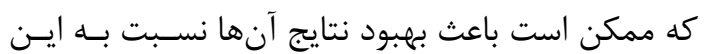
يزوهش شود، مى توان به تنكـتـر بــون منطقـه حاضـر

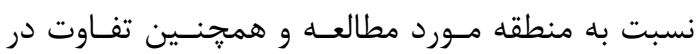
ساختار جنگل ها اشاره كرد. بازسازى DTM، بهمنظــور سـاخت CHM دقيـق نيـز از مهرمترين عوامل تاثير گذار بر روى نتايج است. هرجقــدر اين مدل دقيقتر باشد نتايج حاصل از استخراج ارتفاع و مدل سـازى زيسـت تـوده دقيـقتـر صـورت مسى خيـرد. روشهاى بازسازى DTM با توجه به نوع منطقـه مـورد 
روش قبل (سطح تكدرخت و سطح قطعه نمونه) است.

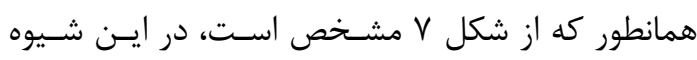
مجموع مقادير زيست توده تكدرختان موجـود در هـر قطعه نمونه بهعنوان متغير وابسته و مقدار زيست تـودها

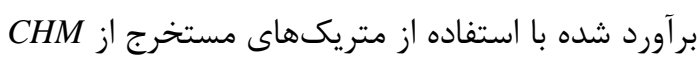

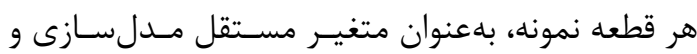

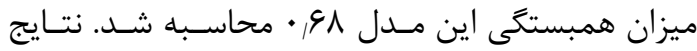

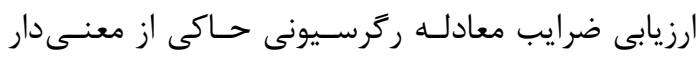

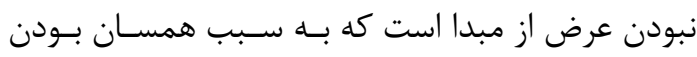

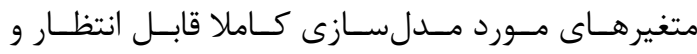
تاييدكننده صحت مدلسازى است (جدول (V)).

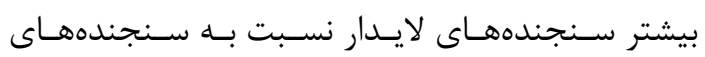

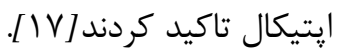

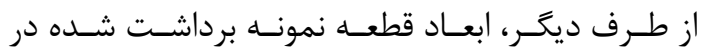

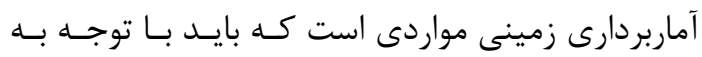

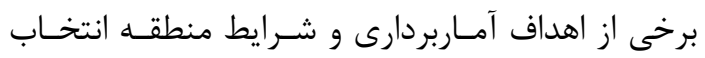
شود. توجه به اين نكات در آماربردارى زمينى در نتسايج مدل سازى در سطح قطعه نمونه مى توانـد بسـيار مـوثر ائر

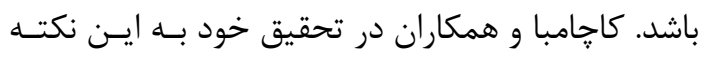

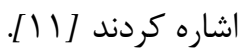

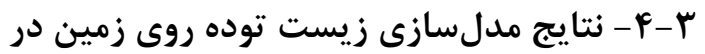
سطح تركيبى

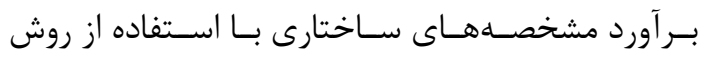

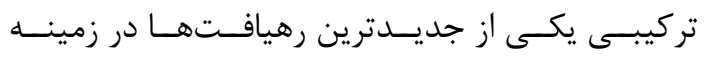

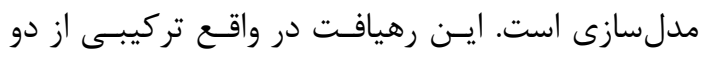

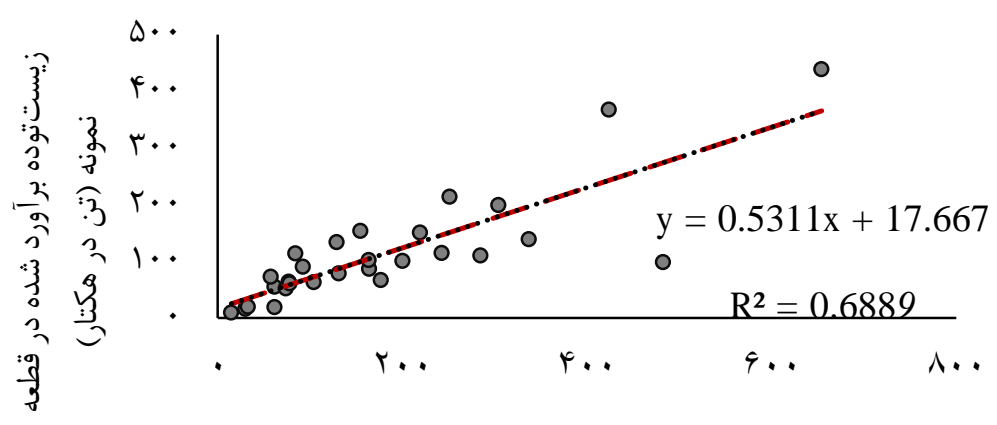

زيست توده واقعى در قطعه نمونه (تن در هكتار )

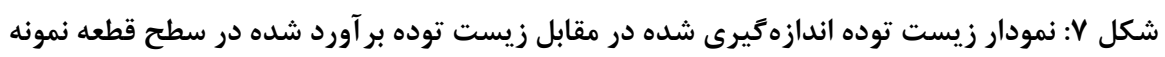

جدول V: ضرايب بر آورد شده مدل برازش يافته ميزان زيست توده در سطح تركيبى

\begin{tabular}{|c|c|c|c|c|}
\hline p-value & 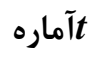 & خطاى استاندارد & مقدار بر آورد شده & متغير ها \\
\hline $.1199 \mathrm{~V}$ & ת 1, 1, & $r \Delta, r \varphi$ & r & عرض از مبدا \\
\hline$\cdot, \cdots)$ & $v / \Delta q$ & - IV & $1, \pi 98$ & زيست توده برآورد شده \\
\hline
\end{tabular}

(جدول(9))، كه در مقايسه با روش قطعـه نمونـه، ايـن

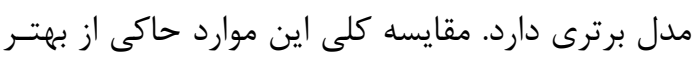

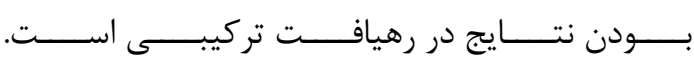

نتايج تجزيه واريانس معادله استخراج شده نشاندهنـده

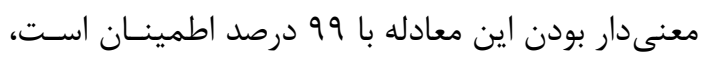

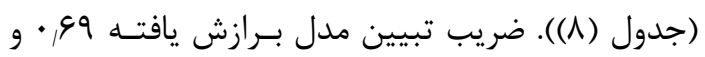

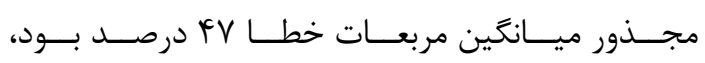




\begin{tabular}{|c|c|c|c|c|c|}
\hline$p$-value & Fاره Fار & ميانغين مربعات & مجموع مربعات & درجه آزادى & منبع تغييرات \\
\hline \multirow{3}{*}{$<\cdot, \cdots \cdot \mid$} & $\Delta \vee / \Delta \wedge r V$ & FTYASA & FYTASV,9V & 1 & مدل \\
\hline & & VMFE & $19 \cdot 9 r r_{1} \cdot r$ & re & خطا \\
\hline & & & 91\%У९9,99 & TV & مجموع \\
\hline
\end{tabular}

\begin{tabular}{|c|c|}
\hline مقادير & معيار ارزيابى \\
\hline$\cdot, 9 \wedge \wedge 9$ & ضريب تبيين \\
\hline - \&V99V & ضريب تبيين تطابق يافته \\
\hline 10,99 & مجذور ميانگين مربعات خطا \\
\hline.$\mu V$ & مجذور ميانگين مربعات خطا نسبى \\
\hline$|1|, 2 \mid$ & 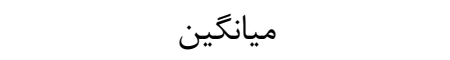 \\
\hline r人 & تعداد مشاهدات (قطعات نمونه) \\
\hline
\end{tabular}

اين تحقيق بـراى اولـين بـار در سـطح كشـور صـورت

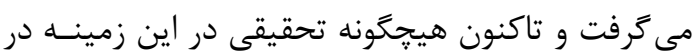
ايران صورت نَخرفته بود تا بتواند به عنوان منبعى بـراى

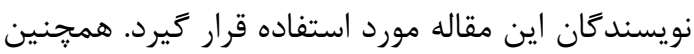

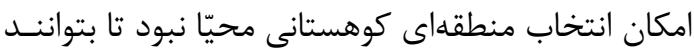

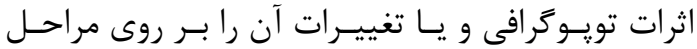
مختلف يزوهش بررسى كنند. اما همانطور كه ذكر شــد ساخت DTM يكى از مراحل بسيار مهـهم در ايـن قبيـل فئل

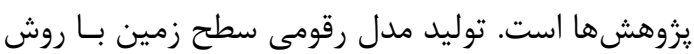

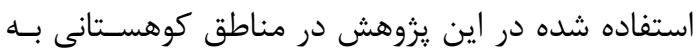

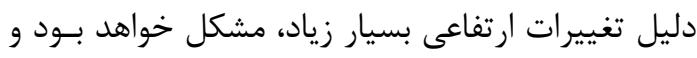
نياز به امكانات خاص خود را دارد. نكته ديكرى كه لازم

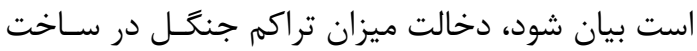
DTM و سطح زمين از روى تصـاوير مشـخص نباشــد، امكـان

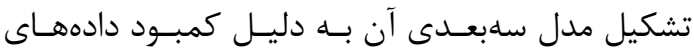

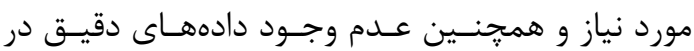
مرحله درونيابى، بسيار سخت است.

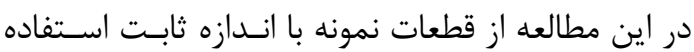

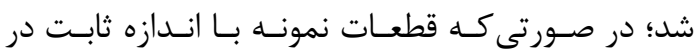

شيوههاى برداشت دادهها جه در مرحله زمينى و جهه در

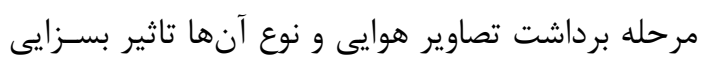
در نتايج دارد. با توجه به اين نكته كه تصويربردارى اين

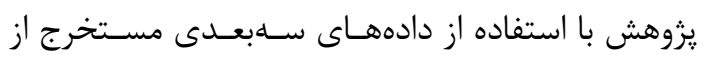
تصاوير صورت زرفت، در مقايسـهـ بـا مطالعـاتى از ايـن

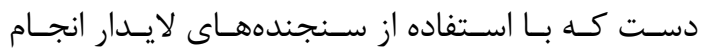

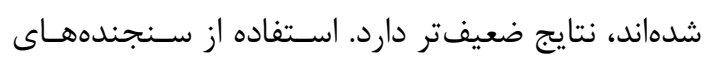
لايدار با تراكم نقاط بالاتر و همجنين سيستم كدگذارى نقاط، دقت بازسازى مدل سهبعدى را بهبود مـى بخشـد.

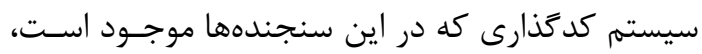
نقاط را با توجه به برخى از يارامترها، كدَّارى كـرده و

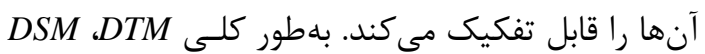
و CHM كه باستفاده از اين سنجندهها ساخته مىشوند

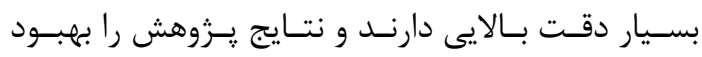
مى بخشند. علاوه بر ايت، نتايج يزوهشهايى از اين دست بـا توجـهـ

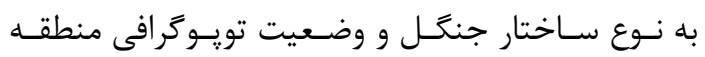
ممكن است تغيير كند. منطقهاى مورد مطالعـه در ايـن يزوهش مسطح بود و نسبت به ديگر مناطق جنگلسى از تراكم كمترى برخودار بود. دلايل اين انتخاب اين بودكه 
برآورد زيستتوده درختان باستفاده از ابر نقاط متراكم ...

محمدرضا كاركر، هرمز سهرابى

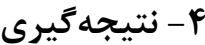

نتايج اين مطالعه نشان داد كه استفاده از مجموعه داده-

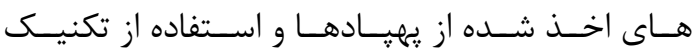

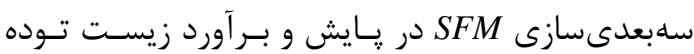

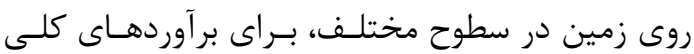
مناسب است اما براى اهداف مديريتى نياز به استفاده از

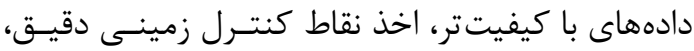
استفاده از شبكه يرواز متقاطع و تحقيقات بيشتر بـراى

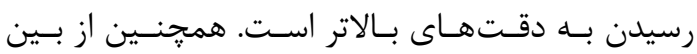

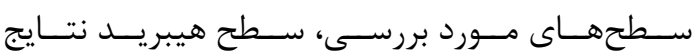
اميدبخشترى ارائه نمود.

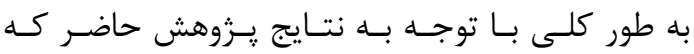

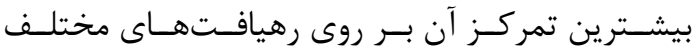
آماربردارى از جمله رهيافتهاى تكدرخت، قطعنه نمونه و تركيبى مى باشـد و ميـزان زيسـت تـوده روى زمسين

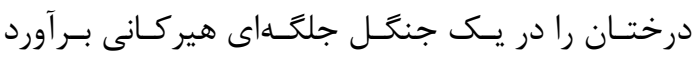
نموده است؛ رهيافت تركيبى توانست در مقايسـه بـا دو رهيافت ديكر عملكرد بهترى از خود نشان دهد. لازم به رهيه

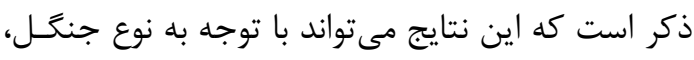

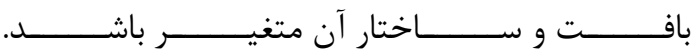

[1] F. Xu, Z. Gao, X. Jiang, W. Shang, J. Ning, D. Song and J. Ai, "A UAV and $S 2 A$ databased estimation of the initial biomass of green algae in the South Yellow Sea", Marine pollution bulletin, vol.128, pp. 408414, 2018.

[2] Z. Zhou, Y. Yang and B. Chen, "Estimating Spartina alterniflora fractional vegetation cover and aboveground biomass in a coastal wetland using SPOT6 satellite and UAV data”, Aquatic Botany, vol.144, pp. 38-45, 2018.

[3] S. Manfreda, M. F. McCabe, P. E. Miller, R. Lucas, V. Pajuelo Madrigal, G. Mallinis, ... and J. Müllerová, "On the Use of Unmanned Aerial Systems for Environmental Monitoring”. Remote Sensing, vol.10, pp. 641, 2018.
سنجش از دور از منابع عدم قطعيت مدل هستند [9 ا، $. r / g$, $r$. بنابراين مطالعات آينــده بايسـد بـهـ بررسـى ابعـاد قطعـه

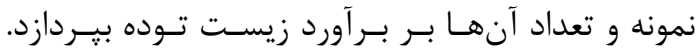

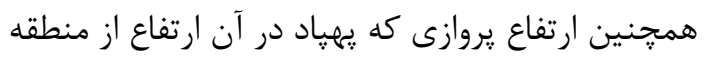

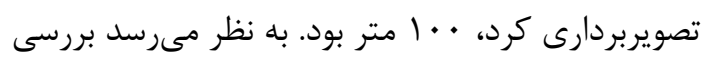
ارتفاع يهرياد بهمنظور تصويربردارى و اثرات ايسن ارتفـاع يرواز برروى دقت DTM، DSM و CHM ضرورى باشـد. تفاوت در روشهـاى سـاخت DTM و بررسـى بهتـرين روش در برآورد ارتفاع و زيست توده نيز يكى از مواردى

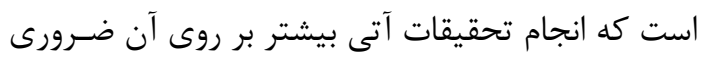

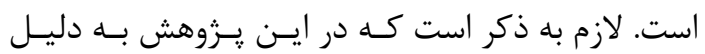
كمبود بودجههاى يزوهشى، بهمنظور توجيسه تصـاوير و

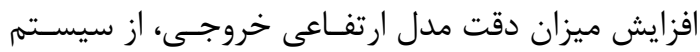

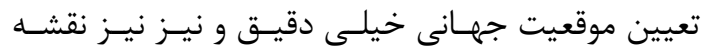
بردارى درختان با ابزارى مانند توتالاستيشـن اسـتفاده موين نشـــ كـاربرد جنــين تجهيزاتـى باعـث بهبـود نتـايج و

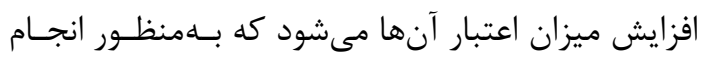

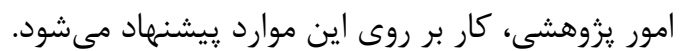

\section{مراجع}

[4] M. Ruwaimana, B. Satyanarayana, V. Otero, A. M. Muslim, M. Syafiq, S. Ibrahim, D. Raymaekers, N. Koedam and F. DahdouhGuebas, "the advantages of using drones over space-borne imagery in the mapping of mangrove forests", PloS one, vol.13, e0200288, 2018.

[5] S. Jiang and W. Jiang, "Efficient structure from motion for oblique UAV images based on maximal spanning tree expansion", ISPRS Journal of Photogrammetry and Remote Sensing, vol.132, pp. 140-161, 2017.

[6] N. Micheletti, J. H. Chandler and S. N. Lane, Structure from motion (SFM) photogrammetry. Loughborough University: British Society for Geomorphology, 2015.

[7] J. D. Stevenson, S. O'Young and L. Rolland, "Enhancing the visibility of small unmanned 
aerial vehicles", Procedia Manufacturing, vol.3, pp. 944-951, 2015.

[8] J. Guerra-Hernández, E. González-Ferreiro, V. J. Monleón, S. P. Faias, M. Tomé and R. A. Díaz-Varela, "Use of Multi-Temporal UAV-Derived Imagery for Estimating Individual Tree Growth in Pinus pinea Stands", Forests, vol.8, pp. 300, 2017.

[9] D. Panagiotidis, A. Abdollahnejad, P. Surový and $V$. Chiteculo, "Determining tree height and crown diameter from high-resolution UAV imagery", International journal of remote sensing, vol.38, pp. 2392-2410, 2017.

[10] W. Li, Z. Niu, H. Chen, D. Li, M. Wu and W. Zhao, "Remote estimation of canopy height and aboveground biomass of maize using high-resolution stereo images from a lowcost unmanned aerial vehicle system", Ecological indicators, vol.67, pp. 637-648, 2016.

[11] D. J. Kachamba, H. O. Ørka, T. Gobakken, T. Eid and W. Mwase, "Biomass estimation using 3D data from unmanned aerial vehicle imagery in a tropical woodland", Remote Sensing, vol.8, pp. 968, 2016.

[12] S. Puliti, H. O. Ørka, T. Gobakken and E. Noesset, "Inventory of small forest areas using an unmanned aerial system". Remote Sensing, vol.7, pp. 9632-9654, 2015.

[13] R. Jing, Z. Gong, W. Zhao, R. Pu and L. Deng, "Above-bottom biomass retrieval of aquatic plants with regression models and SfM data acquired by a UAV platform-A case study in Wild Duck Lake Wetland, Beijing, China”, ISPRS Journal of Photogrammetry and Remote Sensing, vol.134, pp. 122-134, 2017.

[14] D. A. Zimble, D. L. Evans, G. C. Carlson, R. C. Parker, S. C. Grado and P. D. Gerard, "characterizing vertical forest structure using small-footprint airborne LiDAR", Remote sensing of Environment, vol.87, pp. 171-182, 2003.

[15] Y. Seul, P. Hien, J. Soo, M. Hee and M. Wook, "Calculation of tree height and canopy crown from drone images using segmentation", Journal of the Korean Society of Surveying, Geodesy, Photogrammetry and Cartography, vol.33, pp. 605-613, 2015.

[16] V. Luoma, N. Saarinen, M. A. Wulder, J. C. White, M. Vastaranta, M. Holopainen and J. Hyyppä, "Assessing precision in conventional field measurements of individual tree attributes", Forests, vol.8, pp. 38, 2017.

[17] T. Gobakken, O. M. Bollandsås and E. Noesset, "Comparing biophysical forest characteristics estimated from photogrammetric matching of aerial images and airborne laser scanning data", Scandinavian Journal of Forest Research, vol.30, pp. 73-86, 2015.

[18] G. V. Laurin, N. Puletti, Q. Chen, P. Corona, D. Papale and R. Valentini, "Above ground biomass and tree species richness estimation with airborne lidar in tropical Ghana forests", International Journal of Applied Earth Observation and Geoinformation, vol.52, pp. 371-379, 2016.

[19] E. W. Mauya, L. T. Ene, O. M. Bollandsås, T. Gobakken, E. Nasset, R. E. Malimbwi and E. Zahabu, "Modelling aboveground forest biomass using airborne laser scanner data in the miombo woodlands of Tanzania”, Carbon balance and management, vol.10, pp. 28, 2015.

[20] G. W. Frazer, S. Magnussen, M. A. Wulder and K. O. Niemann, "Simulated impact of sample plot size and co-registration error on the accuracy and uncertainty of LiDARderived estimates of forest stand biomass", Remote Sensing of Environment, vol.115, pp. 636-649, 2011.

[21] E. H. Hansen, T. Gobakken, O. M. Bollandsås, E. Zahabu and E. Nosset, "Modeling aboveground biomass in dense tropical submontane rainforest using airborne laser scanner data”, Remote Sensing, vol.7, pp. 788-807, 2015. 


\title{
Estimation of Tree Biomass at Individual tree, Sample plot and Hybrid Level using Drone Images
}

\author{
Mohammad Reza Kargar', Hamzeh Sohrabi ${ }^{2 *}$
}

1- $\quad$ MSc Student of Forest Sciences and Engineering, Faculty of Natural Resources, Tarbiat Modares University

2- Associate Professor of Forest Sciences and Engineering, Faculty of Natural Resources, Tarbiat Modares University

\begin{abstract}
Two-dimensional image conversion algorithms to $3 D$ data create the hope that the structural properties of trees can be extracted through these images. In this study, the accuracy of biomass estimation in tree, plot, and hybrid levels using UAVs images was investigated. In 34.8 ha of Sisangan Forest Park, using a quadcopter, 854 images from an altitude of 100 meters above ground were acquired. SFM algorithm was applied to produce 3D data and the height of the trees was extracted. 28 samples with $30 \times 30 \mathrm{~m}$ dimension were collected and the height and the diameter at the breast height were measured and the biomass was calculated based on a general allometric equation. In order to estimate the biomass at plot-level, the height metrics were extracted from the point cloud. For tree-level, the biomass of each tree was modeled based on the height value derived from CHM for each tree. In hybrid-level, sum of estimated biomass of trees in tree-level was used as the predictor in modeling. The accuracy and precision of the estimates were evaluated using relative bias (rBias), relative root mean square error (rRMSE), and adjusted r square (r2). rRMSE for biomass estimation in Buxus hyrcana, Carpinus betulus, Parottia persica, and other species were 17.56, 7.11, 14.67 and 22.73 percent, respectively. For plot level and hybrid level, rRMSE were 58 and 47 percent, respectively. Based on the result, the most precise approach for biomass estimation is hybrid level and the precision of the estimate is appropriate for overall assessment of forest stands, not for management planning.
\end{abstract}

Key words: UAV, Sisangan, Crown Height Model, Above Ground Biomass, Digital Terrain Model.

Correspondence Address. Forestry Department, Faculty of Natural Resources, Tarbiat Modares University, Tehran, Iran. Tel: +982182880000.

Email:hsohrabi@modares.ac.ir 